\title{
A ORIGEM DA NOITE E POR QUE O SOL É CHAMADO DE “FOLHA DE CARANÁ”
}

Tradução de Bruno Guimarães Revisão técnica de Cesar Gordon

\section{INTRODUÇÃo}

Em ensaio anterior sobre o significado dos ornamentos corporais no noroeste amazônico, sugeri que a caixa em que os ornamentos são mantidos "é um operador espaçotemporal, uma manifestação do sol, um ser vestido com uma brilhante coroa de penas que ordena a passagem do tempo" (Hugh-Jones, 20I4: I6I). Meu objetivo aqui é desenvolver essa ideia, explorando o modo como os povos do noroeste amazônico representam a alternância entre o dia e a noite nos sons e cores dos insetos, pássaros e animais da floresta; nos materiais, texturas e cores de suas casas e posses; no corpo humano; na música e na dança rituais - e como utilizam tudo isto para exercer controle ritual sobre o tempo. Para fazê-lo, baseio-me em um grande conjunto de textos publicados sobre histórias acerca da origem da noite e temas relacionados, registrados junto aos povos indígenas da bacia do alto Rio Negro e áreas adjacentes.

Ao mesmo tempo, espero lançar luz sobre por que, em muitas línguas tukano orientais, os termos para "Sol" e para "Lua" parecem ser constituídos de dois morfemas, o primeiro significando "colmo", o segundo "folha". Por exemplo, em tukano a palavra é muipü, em barasana muhihü, referindo-se mui ou muhi ao colmo e às palmeiras cujas folhas são utilizadas para cobrir as casas, e sendo pü ou hü o termo para "folha". Muipü / muhihü poderiam então ser glosados "folha de colmo" ou "caraná", termo em língua geral utilizado na bacia do Rio Negro para 
se referir amplamente ao colmo, às folhas utilizadas no colmado e também às palmeiras das quais derivam. Para simplificar, daqui em diante utilizarei caraná nesse sentido genérico para me referir aos três sentidos: palmeiras, folha e colmo.

As histórias que me interessam aqui incluem algumas narrativas bastante longas, bem como notas breves e fragmentos. Foram registradas entre os seguintes grupos: os Baniwa, Baré, Kurripaco, Tariano, Kawiyerí e Yukuna-Matapí, falantes de línguas arawak; os Bará, Barasana, Desana, Kubeo, Letuama, Makuna, Taiwano, Tanimuka, Tatuyo, Tukano e Tuyuka, falantes de tukano; e os Kakua, um grupo falante de uma língua makua isolada. No entanto, seria um erro supor que esses grupos representam unidades sociais discretas, cada qual com seu próprio corpus discreto de narrativas, ou que as diferenças entre as versões das histórias consideradas aqui refletem diferenças culturais entre grupos. Minha abordagem adota a posição oposta: tanto em bases empíricas quanto teóricas, trato todas essas histórias como partes do mesmo corpo de ideias. Deixe-me explicar o motivo.

Os povos do noroeste amazônico dividem-se em vários subgrupos nomeados, com implicações importantes para direitos sobre território, recursos, casamentos, status rituais, relações políticas e outros assuntos. Entre os falantes de línguas tukano há, além disso, uma associação geral entre grupos patrilineares e a língua, de modo que grupos exógamos são tipicamente unidades linguísticas. Contudo, na prática, uma vasta cultura do noroeste amazônico se estende para além da ideologia tukano de grupos linguísticos exógamos. Mesmo na área tukano, a residência não obedece necessariamente às regras patrilineares e patrilocais, e reivindicações associadas ao pertencimento ao grupo são frequentemente alvo de disputas. Ao longo do noroeste amazônico há uma profusão de nomes que se referem a grupos de diferentes tipos, dos quais apenas alguns são reconhecidos por pessoas da própria unidade em questão.

Embora representações típicas dos povos do noroeste amazônico e de suas línguas façam coincidir unidades linguísticas e sociais (ver, por exemplo, Epps \& Stenzel, 20I3: IO-I I), como observado acima é importante notar que unidades linguísticas e sociais não coincidem necessariamente, que as pessoas são tipicamente multilíngues e que nomes como "barasana", "makuna", "baré" ou "baniwa" não se referem a unidades sociais ou linguísticas de mesmo tipo. Ainda mais importante, essas unidades não são, de modo algum, como muitas "tribos". Todas elas fazem parte de um sistema social aberto, um conjunto de pessoas que vivem na mesma área geral, casam entre si, trocam comida, bens e serviços, comparecem às reuniões sociais umas das outras e compartilham convenções sociais acerca do uso do espaço, comportamento corporal, modos de fala e interação social. Também trocam vários tipos de informação, incluindo histórias e conhecimento ritual.

Nesse sentido, esses povos são, do ponto de vista sociocultural, mais ou menos iguais. Mas a diferença também é parte integral do sistema, pois são as 
diferenças entre as pessoas e seus grupos, marcadas pelas diferenças nas posses rituais e propriedades imateriais, como a língua, as canções e as histórias, que permitem a ocorrência da troca de esposas, bens e serviços.

Tudo isso tem importantes implicações para as narrativas que examinaremos a seguir. Por um lado, elas demonstram similaridades impressionantes, que transcendem fronteiras linguísticas e territoriais - em termos gerais, contam a mesma história. Por outro lado, indivíduos diferentes, pertencendo a diferentes grupos, contam versões distintas dessas histórias. Aqui a identidade do grupo do contador pode ser pertinente ao que ele ou ela conta, e as próprias histórias podem até mesmo explicar a origem e a natureza da diferença entre os grupos. A identidade de grupo, porém, é apenas um de muitos fatores que concorrem para produzir diferentes versões de uma história. Nos demais fatores incluem-se: aqueles relacionados diretamente com o falante: idade, gênero, papel social e conhecimento das histórias e outras informações relevantes; o pretexto e o contexto social para a história ser contada; a identidade dos ouvintes e o que eles já sabem sobre a história, o que pretendem saber e o que é permitido que saibam.

O fato de que, em dada ocasião, um indivíduo de um grupo conte para um determinado público uma versão de uma história que difere de outra versão, contada em outra ocasião para outro público por outro indivíduo de outro grupo, nos diz muito pouco sobre o que cada indivíduo sabe ou deixa de saber. Em um sistema social aberto caracterizado pelo multilinguismo, por intensas trocas rituais intercomunitárias e pela visitação mútua frequente, os repertórios narrativos certamente se sobrepõem. Um indivíduo com grande conhecimento tradicional está apto a contar a sequência de um mito de variadas maneiras, incluindo breves sumários, detalhes elaborados, detalhes cruciais escolhidos com referência a certas práticas rituais e xamanísticas, até mesmo diferentes versões dos detalhes, aprendidas junto a outros especialistas.

Também precisamos ter em mente que missionários, linguistas e antropólogos que registram tais narrativas introduzem novos níveis de diferença arbitrária, de sorte que o material por eles publicado não fornece um guia confiável daquilo que os informantes sabem ou deixam de saber. Os informantes contam histórias, muitas vezes em espanhol ou português rudimentar, que são moldadas para servir ao entendimento e aos interesses de forasteiros relativamente ignorantes, que por sua vez submetem as histórias a processos de tradução, segmentação, abreviação e outras formas de edição implicadas na longa jornada que vai das notas de campo aos textos publicados. Esses textos, doravante objetivados como "mitos" discretos, estão muito distantes daquilo que o indivíduo contaria a um companheiro de seu grupo. Os diferentes povos da região também tiveram diferentes histórias de contato. Algumas dessas histórias são claramente narradas por pessoas que possuem bom conhecimento, de primeira mão, do mundo tradicional e do ambiente natural retratado; em outras situações, esse não parece ser o caso. 
Finalmente, uma complicação adicional consiste em saber onde uma história termina e outra se inicia. O estudo comparativo de Blixen (20I I) sobre as narrativas sul-americanas da origem da noite delimita a análise comparativa a um único tópico - a noite. Porém, como se esclarecerá adiante, igualmente relevantes para esse tópico são as histórias que não se preocupam explicitamente com a noite, mas que podem ser sequencialmente a elas relacionadas ou que compartilham com elas enredo de estrutura semelhante.

Tendo isto em mente, podemos perceber de pronto que as narrativas de origem da noite não são unidades isoladas. Elas podem ser contadas separadamente e são com frequência publicadas como "mitos" discretos, porém também podem aparecer como partes de um todo maior, no qual são precedidas por outras histórias sobre a terra, as árvores, as folhas de caraná que cobrem o teto, ou podem ser seguidas por histórias sobre músicas, ornamentos, dança, água, mortalidade e outros tópicos.

Por todos esses motivos, em termos puramente empíricos, a noção de um "mito barasana" ou de um "mito tukano" sobre a origem da noite é altamente problemática, assim como qualquer afirmação de que esse "mito barasana" é diferente de um "mito kawiyeri" sobre a origem da noite, por exemplo, ou de um "mito tukano" sobre a origem do caraná. Ademais, como demonstrado há muito tempo por Lévi-Strauss em seus estudos sobre mitologia, há fortes argumentos teóricos para rejeitarmos qualquer noção de mito como unidade discreta e estável. Onde um mito se encerra e outro se inicia é sempre discutível. Seguindo o conselho de Lévi-Strauss (1955: 435-436) de que um mito consiste de todas as suas variantes e que a análise será mais sólida ao levarmos em consideração todas as variantes conhecidas, espero demonstrar que as histórias de nosso conjunto conferem sentido umas às outras e que detalhes obscuros em um texto às vezes são esclarecidos por outro. Um dos objetivos deste ensaio é simplesmente dar sentido às histórias, fornecendo comentários que lancem luz sobre seu contexto de fundo. Tal como se apresentam para nós no momento, as fontes disponíveis são semelhantes a fragmentos de um mosaico danificado. Nossa tarefa é tentar compreender a imagem inteira: algumas partes são suficientemente claras; em outras, porém, podemos apenas vislumbrar seus contornos à medida que reunimos os fragmentos dispersos.

Feitas as advertências metodológicas, vejamos de perto as próprias narrativas. 


\section{HISTÓRIAS SOBRE A TERRA, AS ÁRVORES, AS CASAS E O CARANÁ - UM SOBREVOO}

No noroeste amazônico, as narrativas sobre a origem da noite são geralmente contadas em uma sequência mais longa englobando as origens da terra, das árvores, das casas e do caraná, elementos que constituem os componentes do espaço e do tempo, e são os pré-requisitos da vida social ordenada que os Criadores estabeleceram no início do tempo. Como os rituais sazonais também são parte dessa ordem espaçotemporal mais ampla, não é surpresa que as origens dos ornamentos, canções e danças também se apresentem como parte desse conjunto.

Nessa sequência os episódios possuem, tipicamente, igual estrutura narrativa, que, em termos gerais, se apresenta assim: percebendo a vida como impossível sem terra, árvores, casa, caraná ou noite, um grupo de Criadores, geralmente irmãos, dirige-se à casa de um Dono para pedir que lhes dê aquilo de que precisam. O Dono inicialmente explica que o elemento em questão é perigoso, pode causar vários tipos de infortúnios, além de acarretar duras responsabilidades; deve, portanto, ser tratado com respeito. Ele então fornece aos Criadores uma série de instruções sobre como lidar com o elemento e o controlar devidamente, de modo a torná-lo seguro e evitar perigos e infortúnios. Essas instruções formam a base das magias e de outras atividades rituais que são frequentemente chamadas de benzimentos no português brasileiro e curaciones no espanhol colombiano. Apenas o irmão mais novo, o mais inteligente e atento, protótipo do kumu ou "xamã", segue as instruções. O Dono entrega aos Criadores o elemento em questão dentro de um recipiente, com um grave alerta de que não seja aberto até que cheguem em casa.

Os Criadores partem. O recipiente não apenas lhes parece ser muito pequeno para acomodar tudo o que precisam, como também é extremamente pesado. No caminho, os personagens são incapazes de conter a curiosidade e decidem espiar o interior do recipiente, o que acarreta consequências desastrosas. O conteúdo explode e se espalha em todas as direções. Após várias tentativas frustradas de remediar o problema, o irmão mais novo relembra as instruções relevantes que o Dono lhes dera, e a ordem é restaurada. Do lado positivo, materiais como a terra, as árvores, o caraná e a noite tornaram-se completamente disponíveis, porém, por terem os Criadores desobedecido as instruções do Dono, em vez de ser facilmente manuseáveis e livres de risco, os materiais agora envolvem trabalho árduo, doenças e até mesmo a morte.

Os eixos centrais da variação das histórias sobre o caraná, o sono e a noite, que são objeto de minha especial atenção aqui, incluem:

I. O número e a identidade dos Criadores ou seres primordiais envolvidos. 
Tanto pode ser uma única pessoa, como no caso dos personagens Idn Kamni (Silverwood-Cope, I990) ou Nhãpirikuli (Cornelio et al., I999; Hill, 2009; Trupp, I977), quanto, mais frequentemente, um grupo de dois a cinco irmãos Criadores, o Povo do Céu, Povo do Universo ou Povo da Transformação (Fernandes \& Fernandes, I996; Lana \& Lana, I980) que são conhecidos como Kuwaiwa (Correa, I997), Diroa (Andrello, s.d.), Ümüri Masa (Fernandes \& Fernandes, I996, Reis, 2013), Pamüri Masa (Azevedo \& Azevedo, 2003; Piedade, I997), Bahuari Masa (Fernandes \& Fernandes, I 996), Ayawa (Acaipi, s.d.; Århem et al., 2004; Correa, I996; Hugh-Jones, I979; Oliveira, s.d.; Van der Hammen, I99I), Munully (Bourgue, I976; Correa, I989), Imararimakana (von Hildebrand, I975; I984) ou Karipú Lakena (Fontaine, 20I0; 20I4; Matapi \& Matapi, I984; Matapí \& Matapí, s.d.; Schauer \& Schauer, I975).

2. A identidade e as características do Dono.

Comumente do sexo masculino (ver, contudo, Andrello, s.d.; Silva, I994), ele é tipicamente um Sapo (Acaipi, s.d.; Århem et al., 2004; Azevedo \& Azevedo, 2003; Bourgue, I976; Correa, I989; Correa, I996; Fulop, 2009; Hugh-Jones, I979; Lana \& Lana, I980; Lana, 2009), embora possa ser um Morcego (Palma, I99I), um Grilo (Correa, I996) ou o Chefe dos Grilos (Schauer \& Schauer, I975). Outros Donos incluem Dainali, o Avô do Sono (Barroso Baré, 20 I5; Cornelio et al., I999; Hill, 2009; Romero Raffo, 2003), Tapurinami, Dono do Sono e da Escuridão (Fontaine, 20Io; 20I4; Matapí \& Matapí, s.d.; Schauer \& Schauer, I975) e Je'echú, o Céu-Onça e Pai de Sol e Lua (Trupp, I977).

3. A relação do Dono com os Criadores.

Ele é geralmente o avô (Acaipi, s.d.; Fontaine, 2010; 20I4; von Hildebrand, I975; Matapí \& Matapí, s.d.; Schauer \& Schauer, I975), mas pode ser o tio (von Hildebrand, I975; I984; Schackt, 20I3; Van der Hammen, I99I), o sogro (Bourgue, I976; Cornelio et al., I999; Correa, I989; Correa, I992) ou o cunhado (Fernandes \& Fernandes, I996). Os Criadores tipicamente oferecem ao Dono algo em troca daquilo que buscam, seja coca, tabaco, um ornamento de penas, outros itens de valor, ou uma irmã ou filha.

4. A natureza do recipiente que o Dono oferece aos Criadores.

Esse recipiente costuma ser um vaso, cabaça, castanha ou a caixa de folhas de palmeira que usualmente guardava cocares de penas e outros ornamentos.

5. Se aos Criadores é oferecida a escolha entre várias durações ou gradações da noite.

6. Se a noite e o sono são tratados como componentes separados.

7. Os detalhes geralmente longos sobre o que ocorre durante a extensa noite que sucede à abertura do recipiente. 
Por enquanto não me preocuparei com os pontos 5 e 6 e aqui lidarei brevemente com o ponto 7. Munido desse sumário geral, analiso primeiramente as histórias sobre o caraná e em seguida as histórias sobre a noite. Antes de fazê-lo devo acrescentar duas ressalvas. Meus resumos das histórias são aproximações operacionais, que não têm por objetivo lidar com todos os seus vários detalhes. Minha análise não deve ser vista como uma abordagem exaustiva desse abundante material.

\section{CARANÁ}

\section{Donos}

Nos episódios que antecederam a origem da noite, os Criadores primeiro obtiveram a terra e as árvores, o que lhes permitiu abrir uma clareira e construir a estrutura de uma casa, com estacas e cipós retirados das árvores da floresta. Quando terminam, percebem que lhes faltam as folhas apropriadas para cobrir o teto; então saem em busca junto ao Dono do Caraná.

O Dono do Caraná os alerta que ser dono e chefe de uma maloca é um cargo que acarreta pesadas responsabilidades sociais, requer conhecimento de muitos encantamentos xamanísticos, e que a vida na maloca envolve a recusa do sono e a vigília ao longo da noite, comendo coca e discutindo assuntos importantes (ver, especialmente, Fontaine, 20Io; 2014 e Matapí \& Matapí, s.d.). Ademais, ele os adverte de que o próprio caraná contém perigos ocultos: a terra vermelha, argilosa, que às vezes gruda nas folhas utilizadas para colmar a casa, é um prenúncio da terra que cobre o túmulo, e quando os grilos que se escondem nas folhas cantam na casa durante a noite é geralmente um augúrio da morte (por exemplo, Dutra, 20II: 249; Fontaine, 20I4: 66, nota I7). Finalmente, o Dono oferece-lhes as folhas que almejam, empacotadas dentro de uma caixa de penas (Århem et al., 2004; Correa, I992; I 997; von Hildebrand, I975; I984; Rojas Sabana, I997; Silva, I994), de uma castanha (Århem et al., 2004) ou de um vaso (Schauer \& Schauer, I975), e lhes diz que só devem abrir o recipiente quando estiverem dentro da estrutura da nova maloca. Mas, como vimos, é claro que eles não lhe dão atenção: abrem a caixa no caminho de casa, e as folhas voam em todas as direções, cobrindo o céu e tornando-o escuro. Tivessem eles sido diligentes, as folhas de caraná seriam hoje facilmente encontráveis e colmar a maloca seria uma tarefa branda. Hoje, as folhas do caraná estão aleatoriamente espalhadas pela floresta, e cobrir uma casa é tarefa muito custosa.

Quem é o Dono do Caraná? Nas línguas tukano faladas no noroeste amazônico, a pessoa que controla o material desejado na história é geralmente chamada de "pai", como em ñami hakü (barasana), "pai da noite" (Correa, I992; Hugh-Jones, s.d.) ou "pessoa idosa, ancião", como em pûsua bükü (desana), "caraná velho" ou ñami bükü (barasana, makuna), "velha noite” (Århem et al., 2004; 
Azevedo \& Azevedo, 2003; Hugh-Jones, s.d.). Nesse contexto, os termos pai, chefe ou ancião significam que esses Donos abrangem e encarnam a matéria-prima em questão como uma extensão de sua própria pessoa, de tal maneira que são relativamente maiores e mais poderosos que as demais.

No caso do caraná, o Dono é um pássaro, um gavião (Bourgue, I976; Correa, I989) ou arara (Fernandes \& Fernandes, I996), que incorpora todos os caranás, casas e construções. Suas asas abertas são as duas vertentes do telhado da maloca. Seus ossos são os postes e vigas da estrutura da casa. Seus tendões e veias são as lianas e o cipó-titica utilizados para amarrar os mastros e vigas uns aos outros. Cada tipo de pena de seu corpo - retrizes, rêmiges primárias e secundárias, coberteiras etc. - representam um dos tipos de folhas de caraná que podem ser utilizadas para fazer o colmado e as paredes da casa (Bourgue, I976; Correa, I989; Correa, I996; Fernandes \& Fernandes, I996; Hugh-Jones, s.d.). De um modo bem característico das tendências totêmicas dos Tukano, quando a história é contada em detalhes, cada espécie de caraná e cada padrão de trançado utilizado para prender as folhas às vigas da cumeeira é dito pertencer a um grupo diferente (Correa, I 996; Hugh-Jones, s.d.). Essa informação é um componente essencial dos encantamentos rituais, cuja finalidade é controlar tais matérias-primas, torná-las seguras para o uso e garantir que ofereçam proteção efetiva contra raios, chuva e vários tipos de ataques de forças hostis.

Em sua aparência (barasana, tukano) Ñami Soda ou Ñamiri Sota, o Dono do Caraná é também o Dono da Noite e do Sono, soda ou sota sendo o nome de uma perereca não identificada, cujos grandes olhos dourados e pupilas fendidas lhe conferem aparência sonolenta (possivelmente se trata de Hyla punctata ou de algum outro pequeno hilídeo). Essa incorporação da noite e do sono estende-se a outros atributos desse Dono. Seu nome é, por vezes, Noite ou Noites (Fernandes \& Fernandes, I996; Galvão \& Galvão, 2004; Hugh-Jones, s.d.; Lana \& Lana, I980); ele possui um corpo feito da noite e do dia (Fontaine, 2014: Ioo; Lana \& Lana, I980); possui pálpebras grandes e caídas; veste o sono em sua cabeça sob a forma de um conjunto de plumas ornamentais (Fernandes \& Fernandes, I996); é preguiçoso e dorme profundamente (Århem et al., 2004; Lana, 2009; Matapi \& Matapi, I984), só sendo despertado quando se coloca um caco de cerâmica incandescente em seu peito (Lana \& Lana, I980; Piedade, I997; Reis, 2013) ou quebrando-lhe as canelas com uma borduna ou com o pesado pilão de madeira empregado para transformar em pó as folhas de coca torradas (Barroso Baré, 20I5; von Hildebrand, I975; Matapi \& Matapi, I984; Matapí \& Matapí, s.d.; Rojas Sabana, I997; Romero Raffo, 2003).

Estamos lidando aqui com um exemplo da difundida figura do Dono amazônico discutida por Fausto (2008), um ser que abrange toda uma classe de criaturas ou objetos que são identificados a seu próprio corpo (ver também Costa, 20Io). Nesse contexto, é importante notar que as noções de dono e de 
propriedade também possuem implicações políticas e são uma dimensão importante das responsabilidades e dos perigos inerentes às casas, aos caranás e ao sono, tão enfatizados como temas recorrentes nas narrativas que estamos analisando. $\mathrm{O}$ ato de construir uma maloca representa a reivindicação de um status da parte do homem que inicia o projeto, e um reconhecimento tácito de sua reivindicação por parte daqueles que concordam em auxiliá-lo e que passam, então, a viver sob seu teto. Como (tukano) wiiogü, literalmente "construtor da casa, iniciador da casa", ou (barasana) wii ühü, "chefe da casa", o líder e dono da maloca é identificado com sua casa, sendo responsável por manter vida harmoniosa e organizada para as pessoas que com ele vivem e que ele agora representa. Eles são (barasana) wiiana, "o povo de sua casa", e é o dono quem determina o ritmo dos dias, conduz as conversas ao anoitecer e os despacha para dormir. Sendo o responsável por ordenar o espaço e o tempo, o líder da maloca participa das qualidades de Dono, do qual as casas, o caraná e o sono derivam.

\section{CARANÁ COMO fOLHAS, PENAS E CABELO}

Em nossas histórias, Donos, corpos e recipientes desdobram-se uns nos outros em um denso e estratificado padrão de referência recíproca. A história do caraná nos conta que a maloca é um pássaro cujas diferentes penas produzem as diferentes espécies de caraná utilizadas no colmo. Isso significa que as folhas, as penas, e, por extensão, os ornamentos plumários, são todos uma coisa só. Isso também é sugerido em uma história kubeo, em que a metade superior da caixa contém folhas, enquanto a metade inferior contém os ornamentos utilizados na dança que celebra o final da construção da casa (Correa, I997: I54). O fato de o Dono do Caraná ter dado aos Criadores as folhas armazenadas dentro de uma caixa - que também é usada para armazenar adornos plumários - não apenas confirma a equação entre folhas e penas, como também adiciona densidade a essas associações: a maloca, com seus painéis pintados em cada um dos lados da porta que se assemelha a uma boca, reveste-se do colmo tal qual um dançarino com o rosto pintado reveste-se do cocar de penas (ou como um homem comum reveste-se de cabelo). A maloca é uma pessoa.

Os ornamentos de penas e o caraná também estão conectados em termos de tecnologia, aparência e função. Para produzir o caraná a partir das folhas pinadas da palmeira Lepidocaryum tenue, o tipo de caraná preferido na região, deve-se entrelaçar as pinas individuais de cada folha em densas camadas junto com a raque, amarrada por sua vez, em muitos padrões distintos, à viga feita de tronco de palmeira. A trama de colmo resultante apresenta notável semelhança com as camadas de plumas de um cocar tukano. Este último é feito a partir das camadas de coberteiras de asa de arara, cuja raque é presa a uma faixa larga tecida com fios de fibra de palma. Por essa razão é 
que os xamãs-kumu makuna usam a frase hoa tuti ("penas em camadas") para se referir a uma barreira defensiva. A barreira em questão é construída por meio dos encantamentos verbais do xamã, mas seu referente concreto são as paredes e o teto da maloca que guardam seus habitantes.

Isso também explica os motivos pelos quais os dois autores yukuna-matapi resolveram começar seu livro sobre ornamentos plumários com uma discussão sobre as palmeiras. Escrevem eles:

\begin{abstract}
No caso das palmas, todos os adornos incorporados foram feitos para exprimir uma ideia: que essas palmas ou partes complementaram os tecidos de plumagens ou outras coisas dos adornos rituais. Foram feitos para que os novos seres viventes descobrissem por si mesmos a ideia formada por Je'echú.

As novas gerações teriam que aprender a tecer. Por isso, as diferentes espécies de árvores e bejucos têm um signo, que com sua natureza ensinam a variar sobretudo os tecidos nas plumagens; dessa maneira, os criadores nos deixaram os poderes sobre os tecidos, praticamente são do mundo, por isso hoje em dia os chamamos "mundo de tecido".

A maloca possui sua própria decoração para que possa ter sentido. Quando começou a primeira construção da maloca, os avós imaginaram que a maloca simplesmente não podia ser construída sem que tivesse sido decorada de modo apropriado, pois cada decoração teria seu significado. Depois que acabaram de construir a armação começaram com os tecidos dos puis, um símbolo de decorações da maloca (Matapi et al. 20ı0: I9-20, tradução editorial).
\end{abstract}

A conexão escalar entre cabelo, penas e folhas de palmeiras (semelhantes a penas) também é revelada em um detalhe particular das histórias sobre a origem da noite. Muitas das narrativas fazem questão de definir especificamente o tipo de palmeira cujas folhas foram utilizadas pelos Criadores para fabricar os abrigos e se proteger da chuva torrencial que acompanhou a primeira, e catastrófica, noite. Algumas vezes, as histórias explicam, ademais, que o tipo específico de folha sob a qual os ancestrais se abrigaram determina o tipo de cabelo - liso, cacheado ou retorcido -, dos diferentes grupos tukano (ver Azevedo \& Azevedo, 2003; Fernandes \& Fernandes, I996). Não é surpresa, portanto, que o termo makuna hoa, cujo significado é "pelo, cabelo e penas", possa estender-se semanticamente a "árvores e floresta", porque a floresta também é uma cobertura viva e crescente que evoca a textura e a cor escura do cabelo humano.

A caixa de penas é feita de folhas de (barasana) hēhēhē (Attalea microcarpa), que também são usadas para fazer as paredes da maloca; hēhēhē pertence à classe geral de caraná como "folhas empregadas na construção de casas". A identidade material entre as paredes da maloca e as paredes da caixa de penas sugere que a caixa de penas é, ela própria, uma maloca, e que os ornamentos que ela contém são, à sua maneira, pessoas. Ainda que nenhuma das histórias por mim analisadas indiquem isso diretamente, a identidade entre ornamentos e pessoas foi, em outra ocasião, explicitada em considerações de alguns indígenas kotiria e desana durante uma visita ao Museu Etnológico de Berlim, quando tiveram a oportunidade de ver adornos do noroeste amazônico 
coletados por Koch-Grünberg entre I903 e I905. Os índios ficaram um tanto desconcertados ao descobrir que, em vez de manter os objetos todos juntos na caixa de penas, os zelosos curadores, pensando na melhor forma de conservação, alocaram separadamente os ornamentos de penas em um depósito na reserva técnica exclusivo para as penas, e os ornamentos de ossos no depósito específico de ossos. Os visitantes indígenas tinham uma visão muito diferente de conservação: “Todos esses ornamentos são pessoas", insistiram. "Eles se sentirão solitários se forem separados de seus companheiros. Eles pertencem à mesma maloca, a caixa de penas".

Por outro lado, as histórias deixam bem claro que nos tempos primordiais havia apenas uma maloca, uma construção metonimicamente coextensiva ao universo, à terra (como o piso da maloca), às montanhas (como alicerces da casa) e ao céu (como seu teto de caraná). Dentro dessa casa mítica, o sol pairava inerte no céu, tal qual hoje a caixa de penas paira, inerte, no centro da maloca, suspensa no teto por um cipó. Portanto, temos aqui uma sequência de recipientes análogos, em diferentes escalas, um dentro do outro: universo $\longrightarrow$ maloca $\longrightarrow$ - caixa de penas.

Posto isso, podemos agora começar a entender por que o Dono do Caraná deve ser também o Dono da Noite, pois o caraná, de fato, produz a noite. O interior das malocas do noroeste amazônico é fresco e escuro, sensação reforçada quando se entra em casa vindo do claro sol equatoriano. Em contraste com isso, a primeira coisa que se percebe a respeito da estrutura de uma casa que ainda não recebeu a cobertura de colmo é o seu interior intensamente brilhante - tão brilhante como o "longo dia" narrado nas histórias da origem da noite: um mundo (maloca) sem noite (teto) no qual o sol permanecia imóvel no céu. Cobrir de caraná a estrutura de uma casa não apenas produz uma abóbada protetora, como também veda a entrada da luz, tornando escuro seu interior. Nas palavras de uma história kubeo: "então viu que vinha uma nuvem negra, vinha a folha já tecida cobrindo a casa" (Correa, I997: I52; Trupp, I977: 34: uma folha de Oenocarpus bataua no vaso causa a noite). Com o tempo, e com o desgaste natural do caraná, pontos de luz começam a brilhar através de pequenas frestas da cobertura, destacando-se no interior escuro e fuliginoso da maloca. Esses pontos de luz são estrelas que brilham no céu noturno (ver também Fontaine, 20I4: 79).

Podemos, então, oferecer uma resposta preliminar à questão de saber por que o sol deve ser chamado de "caraná" ou "folha de colmado". O colmo da maloca é como um interruptor de luz: causa a alternância entre o claro e o escuro ou entre o dia e a noite, tal qual o sol movente. Assim, podemos entender por que o personagem do sapo Soda tanto pode ser o Dono da Noite, quanto o Dono do Caraná.

o jogo entre claro e escuro é, porém, mais complexo do que isso, porque o próprio caraná muda de cor com o tempo. Dentro e fora, o colmado de 
uma maloca que acaba de ser feito tem a cor verde-escura das folhas novas e "cruas" do caraná; a cor escura da floresta assimilada ao negro. À medida que o tempo passa, o calor do sol queima o exterior das folhas, levando-as a um tom amarelado-claro, ao passo que o calor e a fumaça do fogo interno resultam em um vibrante tom marrom-dourado e, em seguida, um negro tisne. Simultaneamente, a caixa de penas reproduz uma imagem perfeitamente espelhada desse efeito: feita com tiras sobrepostas de pinas da palma hēhēhē fervidas, a princípio a caixa apresenta a mesmo tonalidade amarelo-solar em toda a sua extensão mas, com o tempo, o exterior se torna escuro, enquanto o interior retém a cor original. Então a natureza alternante do caraná não é apenas um efeito de sua ausência ou presença no telhado, mas também uma propriedade inerente ao material, dependendo tanto do tempo como do agente de mudança (sol claro ou fumaça escura). ${ }^{\mathrm{I}}$

Retornarei à caixa de penas logo adiante. Por ora, estabelecemos que a maloca e a caixa de penas são máquinas do tempo, objetos que sinalizam e causam a alternância de luz e breu ou de dia e noite. Os períodos alternantes do dia e da noite são como sequências de vida e morte, algo que faz da maloca, da caixa e dos ornamentos de penas coisas potentes, mas também fortemente ambíguas, qualidade também compartilhada pelo caraná: a cobertura de colmo torna a vida na maloca possível, porém, escondidos no caraná, estão manchas de terra argilosa e grilos cantantes, os arautos da morte (ver, especialmente, Barroso Baré, 20I5: História de Pûsua bükü).

\section{NOITE}

\section{A origem da noite}

As histórias sobre a origem da noite seguem as da origem do caraná e, como vimos, compartilham a mesma estrutura básica. Nesta seção, destacarei apenas alguns detalhes que são centrais para o meu argumento.

Quando construíram sua maloca e a cobriram com o caraná, os Criadores poderiam ter levado uma vida relativamente tranquila e confortável, não fosse um grande problema. O sol pairava inerte no céu e não havia noite. A ausência de noite significava que não havia ordem temporal, sendo a vida uma jornada de trabalho infinda, sem momentos diferenciados para comer e descansar, de sorte que os alimentos acabaram rapidamente. Determinados a corrigir esse insustentável estado das coisas, os Criadores partiram rumo à casa do Dono da Noite, a fim de obter a noite.

Quando fizeram-no saber de suas intenções, o Dono fez questão de lhes explicar que a noite e o sono lhes custariam muito caro. Com a noite, não haveria apenas o descanso e o sono, mas também um mundo de animais e espíritos perigosos, intrigas, querelas, sonhos ruins e feitiçaria, gula e preguiça, e, por fim, a morte. Por todas essas razões, ele enfatizou que a noite exigiria 
vigilância intensa e precauções rituais especiais, e deveria ser tratada com o mais profundo respeito. Para evitar os perigos, eles deveriam obedecer a regras estritas a respeito da dieta e do sexo, resistir ao sono e se manter despertos ao máximo possível. A noite deve ser um tempo de atividades sérias - contar histórias sagradas, aprender encantamentos xamânicos e utilizar a magia para manejar os ciclos temporais do mundo e afastar as doenças e os infortúnios (para um tratamento detalhado das restrições e magias associadas à noite, ver Fontaine, 2014).

Como para enfatizar que, uma vez que os homens tivessem a noite, teriam também o tempo e, portanto, a morte, algumas versões da história descrevem como, antes de dar aos Criadores a noite, o Dono da Noite deu-lhes primeiro a doença e as feridas - em algumas versões, isso ocorreu porque os Criadores falharam em oferecer algo em troca ao Dono (Bourgue, I976; Correa, I989); em outras, porque este último confundiu o pedido de noite com pedido de doenças e feridas. Em muitas línguas tukano a palavra para "noite", ñami, soa como kami, a palavra para "ferida" (Acaipi, s.d.; Bidou, I972; Correa, I992; I997; Hugh-Jones, I979; s.d.).

$\mathrm{Na}$ noite que antecedeu a partida dos Criadores de volta à casa, levando a nova aquisição, o Dono da Noite ensinou-lhes a lidar com a noite. Antes de abrir o recipiente em que a noite estava guardada, eles deveriam recitar os encantamentos que o Dono ensinara, a fim de manter os perigos noturnos afastados. Deveriam, em primeiro lugar, preparar a bebida fermentada de mandioca e só abrir o recipiente quando se encontrassem no interior da maloca, de preferência no contexto de uma dança ritual. Sob nenhuma circunstância, deveriam abrir o recipiente no caminho para casa. Deixando isso esclarecido, o Dono forneceu ainda um conjunto de instruções detalhadas sobre como dar um fim à noite. Os Criadores, porém, não estavam acostumados à noite e, pouco depois que o Dono iniciou seus ensinamentos, adormeceram. Só o mais jovem se manteve acordado para ouvir toda a lição.

Pela manhã, os Criadores partiram levando a noite em um recipiente. Novamente, estavam curiosos com relação ao grande peso e ao tamanho pequeno do recipiente que, não obstante, emitia estranhos sons. Como em breve iriam descobrir, eram os ruídos de grilos e de outros animais noturnos. A curiosidade logo os venceu e decidiram abrir o recipiente, espiar o interior e então lacrá-lo novamente. Mas, antes que pudessem fazê-lo, a noite escapou, e eles foram imersos na escuridão e em forte temporal. Incapazes de enxergar, eles tropeçavam no escuro, e ficaram encharcados, com frio, e também muito cansados. Por fim, conseguiram fazer um abrigo contra a chuva e logo sucumbiram ao sono.

Algumas histórias oriundas da porção sul do noroeste amazônico contam que, enquanto os Criadores dormiam, o Dono da Noite veio em forma de 
morcego e arrancou-lhes os olhos, para assar e comer em casa, como punição por não terem obedecido a suas instruções. Antevendo o que iria acontecer, o Criador mais novo conseguiu proteger os próprios olhos, conseguindo em seguida resgatar os de seus irmãos mais velhos, recolocando-os de volta em suas órbitas (ver, por exemplo, Århem et al., 2004; Fontaine, 2014; Matapí \& Matapí, s.d.; Palma, I994; Schauer \& Schauer, I975; Trupp, 1977).

Acordando várias vezes, os irmãos mais velhos tentaram, desesperadamente, se lembrar das instruções recebidas, porém sem sucesso. O irmão mais novo interveio e, seguindo as ordens ao pé da letra, finalmente levou a longa noite ao fim. Raiou a alvorada e a ordem foi reinstaurada.

Voltaremos a essas instruções adiante, pois, como variam em função da substância da noite e do recipiente, observaremos primeiramente esses aspectos.

\section{AS SUBSTÂNCIAS DA NOITE}

O que é a noite que escapa para fora do recipiente? Em diferentes versões das histórias, a noite aparece sob várias formas que surgem em muitas combinações distintas. Essa variedade se organiza em três registros principais. Primeiro, há um registro meteorológico, em que a noite figura como uma combinação de nuvens escuras, chuva, vento e raios: mesmo durante o dia, as tempestades amazônicas, com suas nuvens carregadas e trovoadas violentas, podem tornar o mundo bastante escuro. Em segundo lugar, a noite aparece como um registro auditivo, principalmente com o som estridente de incontáveis grilos, gafanhotos e sapos, todos entoando simultaneamente suas vozes. Essas criaturas são conhecidas como os "Velhos da Noite" (barasana ñami bükürā). A esses, são adicionados os sons de vários pássaros noturnos, bem como os gritos do macaco-da-noite e de outros mamíferos noturnos. O terceiro registro é visual. Por um lado, a noite contida no vaso é comparada à terra negra ou à pólvora preta (Fontaine, 20I4; Schackt, 20I3), algo similar à fuligem que adere aos recipientes culinários e ao interior da cobertura da casa. Por outro lado, as histórias mencionam morcegos e pássaros, especialmente os pássaros em que predominam plumas negras. Nesse sentido, o japu-preto (Cacicus solitarius) é alvo de atenção especial (ver Buchillet, I983; Correa, I992: I2 I; Correa, I997: 6I; Lana \& Lana, I980: I I I; Reis, 2013), em contraste explícito com os outros japus "mais claros" (Gymnostinops yuracares, Psarocolius viridis) cujas caudas fornecem brilhantes penas amarelas, muito utilizadas para fazer luminosas coroas e outros ornamentos de plumas explicitamente associados ao sol.

O peso desse contraste aviário vem à baila em várias versões das histórias. Em uma, ao fim da longa noite, o Criador envia o japu claro para verificar se o dia está se aproximando, e então toma as penas desse e de outros pássaros claros para tornar o dia iluminado e nítido (Azevedo \& Azevedo, 2003: I9I). 
Em outra história, o Dono da Noite promete aos Criadores: "se vocês abrirem a caixa no momento certo, vocês terão as penas de papagaios e japus para fazer ornamentos" (ver Buchillet, I983; comparar Correa, I997: I54, em que tanto folhas quanto ornamentos voam para fora da caixa). A hora correta é durante o tempo ritual da noite, não o tempo ordinário do dia, e o local correto é o interior da maloca, não a floresta. Em outra versão os insetos que escapam da caixa são acompanhados pelo macaco-da-noite e por pássaros cujas penas servem para fazer ornamentos - japus, araras, papagaios (Fernandes \& Fernandes, I996: 97). Em outra aparecem tanto os japus escuros como os claros (Galvão \& Galvão, 2004: 430). Finalmente, uma história nos diz que a caixa continha não apenas pássaros, mas os próprios ornamentos de penas (Piedade, I997). Tudo isso é consistente com o fato de que a caixa é, simultaneamente, um recipiente de noite e escuridão e um recipiente de dia e luz. Aqui é importante notar que, apesar de as cores predominantes dos ornamentos de plumas tukano serem amarelo, vermelho e branco, muitos ornamentos contrastam essas cores com pequenos toques de preto, uma alusão discreta à alternância de noite e dia (ver também Hugh-Jones, 2013: 75-76).

Notemos, ademais, que, embora apenas uma versão explicite que o recipiente da noite também contém danças, cantos e conhecimento xamanístico (ver Acaipi, s.d. e Hugh-Jones, 20I2), a própria presença dos ornamentos de penas implica a presença dos cantos, porque ambos são inseparáveis: canções importantes são sempre acompanhadas por danças e pela ornamentação. O significado do emparceiramento dos cantos com ornamentos e do contraste entre cantos dos insetos e cantos dos humanos se tornará mais claro adiante.

Ainda no registro visual da ornamentação, a noite também assume a forma das tinturas corporais azul-escuras (Goldman, 2004), e a alternância da noite e do dia, assim como as qualidades da luz na alvorada e no crepúsculo, é sinalizada por fios de miçangas pretas, brancas, vermelhas e amarelas. Em duas versões, noite e dia são colocados em movimento ao se desatar um nó em um cordão de miçangas que segurava um mundo inerte, semelhante a uma cabaça, em seu suporte (Fernandes \& Fernandes, I996; Silva, I994).

Finalmente, a noite também é retratada com a aparência de formigas (Reichel-Dolmatoff, I97 I; Trupp, I977). Em parte porque as formigas são pretas, e porque, enquanto as corpulentas e doces rainhas aladas da maioria das saúvas voam durante o dia, aquelas de uma espécie em particular chamada (barasana) ñamia, "aquelas da noite", voam apenas antes do amanhecer. Muitas formigas, porém, são criaturas venenosas, e todas elas podem alterar a pele. Estão ligadas à mortalidade e à imortalidade, como discutiremos abaixo. 


\section{CAIXAS E POTES: ENTRE A ESPERANÇA E O DESESPERO}

Deixando de lado menções a um cesto (Cornelio et al. I999) e a um saco (Hill, 2009), nossas histórias concordam que a noite e o sono eram armazenados em uma cabaça (Århem et al., 2004), uma castanha (Århem et al., 2004; Fontaine, 2010; 20I4), um pote (Acaipi, s.d.; Bidou, I972; Correa, I989; I996; I997; Palma, I99I; I994; Romero Raffo, 2003; Trupp, I977) ou em uma caixa (Andrello, s.d.; Buchillet, I983; Correa, I992; I997; Fernandes \& Fernandes, I996; Fulop, 2009; von Hildebrand, I975; Lana \& Lana, I980; Lana, 2009; Piedade, I997; Reis, 2013; Schauer \& Schauer, I975; Silverwood-Cope, I990), costumeiramente identificada como a caixa de penas. Seguindo essa pista, suspeito que a cabaça prototípica é, provavelmente, a pequena cabaça selada com cera e contendo tintura de carajuru, rapé e outras substâncias potentes que são mantidas dentro da caixa.

Em relação à castanha, em uma versão ela é identificada como a semente da palmeira Lepidocaryum tenue, a fonte preferida de caraná (Fontaine, 20I4: 50, nota 8), porém, em outras versões, as castanhas parecem corresponder às castanhas de tucum, pretas e polidas, que são utilizadas para guardar a tintura de carajuru. Isso as incluiria, com a caixa de penas e as cabaças seladas, em um conjunto de objetos relacionados aos adornos. Como esferas negras que liberam a escuridão e o sono, essas castanhas apareceriam como contrapartes das esferas brancas, os olhos e órgãos da visão que o Dono da Noite roubou dos Criadores como punição pelo fato de eles terem desprezado seus conselhos sobre como e onde abrir o recipiente da noite. Noite e Sono são equivalentes a um estado de cegueira semelhante à cegueira literal dos Criadores, quando da retirada de seus olhos pelo Dono da Noite. No instante em que os olhos são recuperados, os Criadores conseguem enxergar novamente, justo quando o alvorecer encerra a longa noite. Uma versão distinta desse emparceiramento de preto e branco é encontrada na seguinte passagem de uma história tariano:

Foi com a escuridão que as pessoas adquiriram a parte preta dos olhos e passaram a sentir sono. Os animais noturnos dormem durante o dia, durante esse período o olho deles é todo claro - e veem o dia como noite. À noite, o olho deles é preto - e veem a noite como dia (ver também Fontaine, 20I4: 64-65).

Se cabaças, castanhas e a caixa de penas pertencem todas a um mesmo conjunto, o que dizer dos potes? Nenhuma de nossas histórias nos dá informações sobre o tipo de vaso utilizado, mas muitos elementos indicam que seu protótipo seja o pote de cerâmica feito para guardar veneno de curare. Consideremos o seguinte:

O curare é uma substância preta e resinosa, ideal para a imagem da noite como substância e, onde há a descrição, o recipiente de cerâmica da noite é cuidadosamente selado, com uma tampa amarrada por fios, assemelhando-se muito a um pote de curare. Assim como o Dono da Noite, o Dono 
do Veneno (barasana Rima Hino, "Anaconda Venenosa"), personagem de outro conjunto de histórias, também tem o sono pesado, só podendo ser despertado por cacos de cerâmica incandescentes ou golpes em sua canela. Tal como o pote da noite, o pote de curare da Anaconda Venenosa é repleto de insetos e criaturas relacionadas, dessa vez com ênfase no veneno. A tampa é a teia de uma aranha venenosa, a linha que segura a tampa é uma centopeia venenosa e a espátula, a cauda de um escorpião. Na linguagem xamanística, a frase (makuna) ñami rima oka, "o veneno da noite", é utilizada como um termo abrangente para se referir a todos os diferentes perigos da noite, de animais assustadores a espíritos malevolentes, passando por intrigas e desavenças, pesadelos e preguiça, feitiçaria, doenças, velhice e morte (Århem et al., 2004; Hugh-Jones, s.d.). Finalmente, o pote da noite era, de fato, um pote de veneno não só porque fora precedido por um pote cheio de chagas, como vimos, como também pelo fato de que a aquisição da noite colocou o tempo em movimento e, com a alternância de dia e noite, veio a alternância de vida e morte.

De modo previsível, os temas da mortalidade e da imortalidade permeiam essas histórias. O Dono da Noite e os Criadores que o visitam são seres imortais que vivem, hoje, como fontes contínuas de poderes e conhecimento xamanísticos. Porém, como resultado da estupidez dos Criadores e da raiva do Dono, os mortais comuns estão condenados a falecer (ver, especialmente, Matapi \& Matapi, I984).

Uma manifestação da imortalidade do Dono da Noite consiste na divisão do seu corpo entre noite e dia, característica já apontada. Outro exemplo é sua habilidade de se renovar, mudando a própria pele. Quando o despertam de seu sono profundo, ele parece velho e feio, com o cabelo emaranhado e o rosto coberto por barba, mas, então, ele remove seu ser velho como uma pele ou máscara, que arranca da cabeça e do rosto, pendurando-a em uma viga de sua maloca. Em seguida, sai para se lavar e retorna limpo, novo, com o rosto pintado e portando brincos e colares (Azevedo \& Azevedo, 2003; Lana \& Lana, I980).

O tema da mudança de pele e da imortalidade que figura proeminentemente em nossas histórias nos leva novamente ao veneno e aos insetos. Os insetos desempenham um papel central nas histórias do caraná e da noite: o Dono da Noite é o Pai dos Grilos (Schauer \& Schauer, I975), e o recipiente da noite contém formigas, grilos, vaga-lumes e outros insetos. Os insetos são apropriados em virtude de sua cor preta, seus cantos e seus voos noturnos, bem como pelo fato de também trocar suas peles, um signo de imortalidade compartilhado com cobras venenosas e aranhas.

Tais relações evidenciam-se na história, bastante difundida na região, de uma divindade que oferece aos ancestrais da humanidade folhas de coca armazenadas em uma cabaça infestada por criaturas venenosas, que picam e ferroam. Os ancestrais se recusaram a comer dessa cabaça, e, por causa disso, hoje, todas as pessoas são mortais. Já as cobras, aranhas e insetos venenosos 
comeram da cabaça, então puderam trocar de pele e viver eternamente (ver Fulop, 2009: 49-5 I e comparar com Hugh-Jones, 2013: 238 ss.). Essa história, intimamente ligada à origem da noite (ver, por exemplo, Fulop, 2009), é também uma transformação de outra história em que as mesmas criaturas venenosas roubam seu veneno do pote de curare da Anaconda. A mudança de pele, a imortalidade e o veneno estão claramente conectados.

O pote que guardava a noite era, de fato, um cálice envenenado, pois, conquanto as gerações possam se suceder, umas após as outras, como o dia e a noite, todo indivíduo está fadado a morrer. Por contraste, os ornamentos plumários são eternos. Os primeiros seres pré-humanos eram criaturas de espírito puro, sem substância corporal mortal, que assumiram a forma desses ornamentos e ainda hoje neles permanecem existindo, dentro de sua maloca- caixa de penas. Durante os rituais que garantem a reprodução social e a fertilidade das estações, os dançarinos que se adornam com tais ornamentos plumários fazem um breve retorno ao estado ancestral e imortal.

Se minha hipótese sobre o pote recipiente da noite como um equivalente do pote de curare está correta, podemos concluir que, ao apresentar as caixas de ornamentos imortais e os vasos de veneno como duas alternativas de recipiente para a noite, nossas histórias expressam a tensão entre a esperança e o desespero ou entre a imortalidade e a morte.

Seja como for, é certo que os distintos recipientes vinculam-se a duas formas alternativas de controlar a noite: potes e castanhas junto a barulhentos e fastidiosos insetos; caixas junto a pássaros coloridos, canto e dança dos humanos.

\section{RUÍDOS NA FLORESTA}

Como já vimos, antes de dar aos Criadores o recipiente contendo a noite, o Dono forneceu cuidadosas instruções sobre como lidar com seus perigos. Algumas instruções se referem ao local e momento certos para abrir o recipiente. Nem todas as versões trazem detalhes, porém, quando é o caso, fica evidente que os Criadores deveriam abrir o recipiente no interior da maloca e, de preferência, no contexto de uma dança ritual, apropriado para os encantamentos xamanísticos que protegem as pessoas dos perigos associados à noite. ${ }^{2}$ As outras instruções dizem respeito a como pôr um fim à primeira noite e garantir a alternância regular e bem medida entre o período noturno e o diurno.

Nas histórias em que a noite está dentro de uma castanha ou pote, as instruções indicam que os Criadores devem reproduzir os padrões dinâmicos dos sons dos insetos que marcam a passagem da noite, em particular o período que vai da meia-noite ao alvorecer. Em algumas histórias, os Criadores apenas criam ou se transformam em animais ou pássaros, que então emitem os sons que indicam a proximidade do amanhecer. ${ }^{3}$ Porém, em outras histórias, o Dono 
da Noite fornece instruções explícitas para que os Criadores imitem os sons dos insetos noturnos, a "Gente Velha da Noite" (kubeo tiritiriarü). Por exemplo, em uma história kubeo (Correa, I997), o Dono da Noite diz aos Criadores que eles devem, primeiro, repetir "ti-ti-ti, ti-ti-ti", depois "tiri-tiri-tira-tira, tiri-tiri-tira-tira"; então, "ti-ti-tira-tira, ti-ti-tira-tira", e, assim, se fizerem tudo certo, escutarão os insetos respondendo aos diferentes chamados, conduzindo a noite para que chegue ao seu término e permitindo o romper da alvorada. ${ }^{4}$

Obviamente é muito difícil decorar tudo isso, sobretudo quando se está tropeçando no escuro e na chuva, molhado até os ossos, mesmo que se tenha conseguido, antes de mais nada, ficar acordado para ouvir todas instruções. Assim, os irmãos mais velhos sempre falham, e é com muita dificuldade que o Criador mais novo consegue, afinal, lembrar-se das instruções e levar a primeira noite catastrófica ao seu fim.

\section{CANTOS E DANÇAS NA MALOCA}

Nas narrativas em que a noite estava contida na caixa de penas, as instruções se tornam mais elaboradas. Embora uma versão incluísse ainda o episódio da imitação dos ruídos dos insetos, no conjunto a ênfase recai na manipulação da caixa de penas, nos atos de colocar e de retirar os adornos, nos cantos e no uso de um chicote ritual ou de uma lança-chocalho. Observemos essas instruções em detalhe, examinando algumas versões da história que são, evidentemente, transformações umas das outras:

A. Antes de entregar a caixa, o Dono da Noite se adorna com enfeites plumários e então empurra a caixa pelo chão da casa com a ponta dos pés. Movendo a caixa desse jeito, o Dono sugere que a caixa é leve. Os Criadores, porém, descobrem, depois, que, para eles, a caixa é excessivamente pesada. A movimentação da caixa pelo chão da maloca marca a passagem do tempo: cada empurrão com a ponta dos pés significa minuto e, a cada hora, o Dono bate na caixa com seu bastão (ou chicote) e invoca as criaturas da noite, cantando "titi titi", como já mencionado. Começando no crepúsculo, durante toda a noite o Dono empurra a caixa do fundo da casa, até a porta da frente, isto é, o alvorecer. Ele então remove seus "adornos de sono", entrega a caixa aos Criadores e volta a dormir (Buchillet, I983; Lana \& Lana, I980, Lana, 2009).

B. Em outra versão, somos informados de que, em vez de cantar ou bater na caixa com um bastão ou chicote, o Dono usa a lança-chocalho para imitar o som dos insetos da noite. Mais tarde, após os irmãos mais velhos terem falhado, o Criador mais novo consegue terminar a noite ao utilizar a lança-chocalho para imitar os insetos, chocalhando inicialmente à meia-noite e depois quatro vezes mais, até o amanhecer. Ainda em outra versão, os Criadores usam "varas 
de pesca" para golpear a caixa, primeiro para abri-la e ver o que ela contém, depois para persuadir alguns dos grilos a voltar para dentro, trazendo a noite ao seu fim (Andrello, s.d.).

\section{Outra versão segue-se assim:}

Ele já vinha fazendo cerimônia com seu chocalho. Por isso, hoje em dia, se escuta no começo da noite os insetos cantando.

Essa caixa tinha todos os ornamentos e enfeites de dança. Ele empurrava a caixa com o pé e explicava: primeiro, na caixa tem um colar de miçangas, depois tem osso de veado, esclarecendo como cada objeto deveria ser usado depois. Mandou deixar peneiras e colocou em cima delas. Cada vez que começava a explicar, eles cochilavam. Depois de cada explicação, ele dançava. Disse que nos quatro pontos há ganchos, nos quais pendia a noite. Depois da meia-noite ele ainda ensinou como guardaria os instrumentos e ornamentos que estava usando. Primeiro, explicou como desmanchar a amarração dos ganchos - os nós que os seguram - e guardá-los na maloca. Depois ele foi guardando os ornamentos, após um movimento da dança. Firam tirando cada enfeite até amanhecer, quando fechou a caixa e entregou para eles. Por isso, até hoje os Baya dançam durante toda a noite (ver Århem et al., 2004: I89; ver também Trupp, I977: 32 para uma sequência similar de ornamentos e danças).

Na sequência, após os dois irmãos mais velhos não lograrem pôr fim à noite, eles dão ao irmão mais novo um chicote ritual, confeccionado a partir de um broto de árvore, permitindo que ele tente a sorte.

Sendo o último, o mais inteligente, ele se ornamentou com os colares de miçanga, conforme havia visto na maloca, e cocares de penas de arara. Ele pronunciava o nome de cada enfeite e ia juntando-os e ornamentando-se. À meia-noite, já estava pronto, com todos os adornos que os Baya usam. Após isso, nessa hora todos os insetos param de zoar. Ele começou a reza, desmanchando os ganchos presos no norte, sul, leste e oeste. Também começou a tirar e guardar os ornamentos (Århem et al., 2004: I9I).

D. Uma última versão narra o seguinte:

Ñamiri começou a explicar como desmanchar o nó da corda de miçangas que mantinha a terra presa no seu suporte, impedindo o movimento do dia e da noite. Em primeiro lugar, disse que eles deviam pensar que, um dia, as futuras gerações teriam um tempo reservado para dançar os cantos dos Kapiwaya, os cantos que acompanham a tomada de caapi, e que essas danças iriam durar uma noite inteira. A noite equivale ao tempo de duração da dança dos Kapiwaya (Fernandes \& Fernandes, 1996: 94).

Daí, o irmão mais novo põe fim à noite: "calculando que era o tempo do encerramento da dança dos Kapiwaya, começou a cantar a cerimônia de dividir o tempo, desmanchando o nó da corda de miçangas" (Fernandes \& Fernandes, I996: 98). Ele entoa um canto cujos quatro versos distintos se referem a uma sucessão de diferentes miçangas coloridas: vermelhas como o 
carajuru - crepúsculo; pretas como os insetos noturnos - noite; amarelas como o ocre - primeira luz; então, miçangas brancas - dia; os dois primeiros versos com o refrão "titi titi", os últimos dois com "titi tiri sira sira sira" (Fernandes \& Fernandes, I996: 98-100).

\section{A LANÇA-CHOCALHO E A CAIXA DE PENAS}

Muitos pontos surgem desse conjunto de variantes. Para começar, as histórias apresentam o controle da noite em diferentes registros: um auditivo e outro combinando o auditivo com o visual. Esses dois registros são predominantes e associam-se não exclusivamente aos dois tipos de recipientes, a castanha ou pote, de um lado, e a caixa de ornamentos de penas, de outro. Um conjunto de instruções trata de insetos, e a gradação cromática se aplica apenas no nível dos sons: os diferentes barulhos dos insetos indicam diferentes partes da noite, mas os insetos e seus recipientes continuam negros como a noite. $\mathrm{O}$ tempo noturno é uma experiência essencialmente incolor, em que o sentido auditivo é fortemente ampliado - e a noite amazônica é preenchida por uma extraordinária cacofonia de sons estranhos e desordenados.

O outro conjunto de instruções versa sobre os pássaros não apenas porque a caixa é um recipiente dos ornamentos de penas, mas também porque há aí um contraste implícito entre os ruídos dos insetos noturnos e incolores e os cantos dos pássaros diurnos e coloridos, que fornecem a matéria-prima e os protótipos para o canto e a dança dos homens. Os pássaros são animais da floresta, como os insetos, porém, ao contrário destes, aqueles podem ser domesticados e trazidos para a casa como animais de estimação e fonte de penas. Nos mundos das aves e dos humanos, o canto e a ornamentação colorida andam juntos.

As instruções associadas à caixa de penas são cromáticas em vários níveis: implicam, primeiramente, colocar e retirar uma série ordenada de objetos que são inerentemente coloridos e utilizados em uma sequência ordenada, da parte da frente para a parte de trás da cabeça e, em seguida, no restante do corpo (ver Hugh-Jones, 20I4). A sequência da ornamentação é intercalada com uma sequência de diferentes versos dos cantos, sonoridade humana, organizada e cromática, contrastante com a cacofonia indiferenciada dos insetos da floresta e que se faz acompanhar por uma série de danças. Aqui, são o canto e as danças dentro da casa, em vez dos ruídos da floresta, aquilo que ordena o tempo. Finalmente, as danças rituais que ocorrem em diferentes estações do ano exigem diferentes ornamentos e diferentes instrumentos musicais (Matapí et al., 2010: 36).

As narrativas em que o Dono da Noite se ornamenta, dança e canta não são apenas sobre a origem da noite, mas também, por consequência, sobre a origem dos adornos plumários e dos cantos e músicas que os acompanham. Uma versão makuna afirma explicitamente que "nessa noite a palavra de co- 
nhecimento estava se originando - keti oka; nesse momento, os Ayawa não souberam manejá-la e deixaram-na escapar. Surgiram as danças boas para a gente, e eles também deixaram-nas escapar" (Acaipi, s.d.). A demonstração do Dono da Noite nada mais é do que uma sessão de ensinamentos rituais, e as narrativas refletem com precisão o que realmente ocorre durante as danças rituais no noroeste amazônico. Os adornos plumários são especialmente associados às danças que acontecem durante a noite. O ritual, como um todo, consiste em uma sequência de duas danças-canções. Durante a primeira dança-canção (barasana basa müta, "a pequena dança"), os dançarinos vestem apenas simples diademas solares, compostos de plumas vermelhas e amarelas. Então, no crepúsculo, a caixa de penas é aberta, conjuntos completos de adornos são distribuídos entre os dançarinos, e a segunda dança-canção (barasana basa bükü, "a grande dança ou dança principal") tem início e continua até depois do alvorecer.

Conforme indicado nas narrativas, a sequência temporal da dança é marcada por uma mudança no tipo de ornamentação e, quando a noite começa, a caixa é aberta, e os ornamentos são distribuídos aos dançarinos, assim como as folhas e os ornamentos foram distribuídos pelo mundo. A duração da noite é segmentada por uma sequência de diferentes versos alternados com longas sessões de cantos. Então, a partir da meia-noite, as sessões de canto são marcadas pelo som ritmado da lança-chocalho do kumu. Ao longo da noite, o kumu lança encantamentos sobre cabaças de coca e outras substâncias especiais. Essa é a "reza" que, nas narrativas, desata os nós e mantém o tempo em curso. Trata-se de um conjunto de procedimentos também chamado de "curando o tempo". Depois do amanhecer, em plena luz do dia, a dança termina, e os dançarinos removem seus ornamentos e os guardam novamente na caixa.

Por fim, qualquer pessoa indígena que narra ou escuta as histórias sobre a origem da noite sabe que as danças ali referidas estão intimamente ligadas aos ciclos sazonais. As danças celebram a época de derrubar e queimar as roças e a época de abundância de alimentos que resulta dos frutos sazonais das árvores, bem como as formigas voadoras, a desova dos sapos e a piracema, que seguem o padrão sazonal das chuvas. Elas também marcam os eventos importantes dos ciclos temporais humano: a primeira menstruação, a iniciação de um rapaz ou a inauguração da nova maloca de um chefe. O tempo que desabrocha nessas narrativas não é apenas o tempo da noite e do dia, ou o ciclo de vida humana, do nascimento à morte, mas também é o tempo cósmico e cíclico das estações do ano. Nem todas as narrativas o afirmam explicitamente, mas isso se depreende de inúmeras referências à origem de diferentes espécies e dos frutos das árvores contidas nas narrativas sobre a primeira longa noite (ver, especialmente, Acaipi, s.d. e também Århem et al., 2004; Correa, I989; I996 e Matapí \& Matapí, s.d.), bem como de certos detalhes, como quando aprendemos que os animais libertados do recipiente da noite se 
tornaram constelações celestes (Andrello, s.d.; Rojas Sabana, I997), ou que determinados conjuntos de estrelas são ornamentos plumários (Oliveira, s.d.).

Um segundo ponto é que as histórias evidenciam que a caixa de penas é, de fato, o sol. A caixa é feita de palmas claras e amarelas, como o sol; contém um conjunto de ornamentos cujas cores predominantes, amarelo e vermelho, são as mesmas do sol; pende acima do centro da maloca, tal qual o sol pendia antes da liberação da noite; e seu movimento atravessando o chão da maloca marca as divisões da noite, do crepúsculo e da alvorada. Considerando que a parte dos fundos da maloca volta-se para o oeste, e que a parte da frente volta-se para o leste, podemos deduzir que a passagem da caixa pelo chão da maloca representa o caminho noturno do sol pelo mundo subterrâneo, que o leva do oeste até seu novo surgimento, no leste. Um terceiro ponto se relaciona com o chicote ritual e a lança-chocalho, objetos que são empregados tanto para bater na caixa de penas como para imitar o som dos insetos, e que são, ambos, portanto, instrumentos para controlar o tempo. Os chicotes são feitos a partir de brotos finos de árvore, descascados, que também servem para confeccionar varas de pesca. São empregados para bater nas pessoas a fim de torná-las fortes, principalmente durante os ritos de iniciação. Porém, às vezes, também são usados para castigar mulheres e crianças (ver Hugh-Jones, 2013). Em algumas línguas tukano, os chicotes são chamados de "vara de tocandira" (barasana heta waso), pois, assim como as venenosas formigas tocandira, eles possuem uma ferroada dolorosa. Os chicotes são, portanto, associados tanto a insetos quanto a veneno. Por fim, são também instrumentos musicais - nas narrativas, eles são usados para acertar a caixa de penas, e, nos rituais, o kumu os agita agressivamente para produzir um intenso ruído sibilante. A propósito, as formigas tocandira também emitem um chiado audível.

A lança-chocalho e o chicote são, funcionalmente, equivalentes: ambos fazem par com a caixa de penas; ambos produzem sons relacionados aos insetos (a lança imitando o som dos grilos, e o serpentear do chicote, usado para bater na caixa de penas, anunciando a picada da formiga); e ambos são armas, o chicote por razões óbvias, a lança aparecendo como arma em outras histórias (ver, por exemplo, Galvão \& Galvão, 2004: 404). Finalmente, ambos são utilizados como alternativas para fins bastante similares, e um pode servir de substituto ao outro: em uma das versões, o Dono da Noite usa a lança dentro de casa, ao passo que os Criadores precisam empregar um chicote (feito às pressas para tentar repetir as instruções) na floresta. Podemos dizer que o chicote, um mero broto descascado, pertence à floresta, já a lança, que equivale a um chicote sofisticadamente trabalhado, pertence à casa - tal qual o barulho dos insetos pertence à floresta e os cantos e danças humanas pertencem à casa.

A lança-chocalho (barasana besuwü yukü; tukano yeegü) é um instrumento que parece ser exclusivo da região do noroeste amazônico. Ela consiste de 
uma haste cônica de madeira de lei, de um vermelho forte, finamente polida, com cerca de dois metros de comprimento. A extremidade mais fina termina em uma ponta afiada. Acima da ponta há uma dilatação oca, com fendas em suas laterais contendo pequenos seixos de cristal. A lança é, efetivamente, um maracá encrustado em uma haste longa e flexível. É tocada simplesmente chacoalhando-se-a com as mãos - "titi titi, titi titi" -, ou segurando-se a extremidade mais fina com uma das mãos, e batendo na haste com a outra, ou ainda dando-se leves pancadas contra o ombro, de modo a fazê-la vibrar em toda a sua extensão, o que resulta no soar do chocalho - "tiriri tiriri sira sira".

O topo da lança é ricamente decorado. Na extremidade, há dois dentes de osso ou de presa de animal. Logo abaixo há uma seção entalhada, na qual o baixo relevo é preenchido com giz branco. O entalhe consiste de duas figuras semelhantes, cada uma com medalhões em lados opostos, separados por uma forma que lembra ampulhetas. Os medalhões superiores representam o sol; os inferiores representam a lua, e as ampulhetas são os suportes da cabaça. Abaixo, há três penachos, o primeiro de penas pretas de mutum, o segundo de penas vermelhas e amarelas de cauda de tucano, o terceiro de penas brancas de abutre e outras aves de rapina. Entre esses penachos há bandas de mosaico, feitas a partir das pequenas e iridescentes penas azuis de uma espécie cotinga, cada uma cuidadosamente colada à haste. Após o penacho branco, o entalhe se repete, depois, outro penacho branco abaixo. Finalmente, quando está sendo utilizada, uma corda de pelo de macaco, terminando em um par de vivas penas amarelas de japu com franjas vermelhas e amarelas de penas de tucano, é amarrada próxima ao penacho mais baixo. Esta corda de pelo parece ecoar as "largas mechas de cabelo humano retiradas quando o objeto é vendido a um branco" descritos por Stradelli (Biocca, 2007: 52), pois tanto os cabelos humanos quanto os pelos dos macacos possuem conotações de periodicidade (ver Hugh-Jones, 20I4: I64). A lança é um instrumento de som e luz, com um chocalho em uma extremidade e vivas penas celestiais na outra. O pelo ou cabelo e as imagens do sol e da lua enfatizam seu papel como instrumento de controle do tempo.

Esse belo instrumento é controlado pelo kumu, que cuida dos procedimentos rituais coletivos, entoa os encantamentos e desempenha outros cuidados xamanísticos a fim de proteger os participantes das ameaças da noite e dos perigos da estação à qual a dança é associada. O kumu emprega a lança para marcar as divisões da noite, fazendo-a soar primeiramente por volta da meia-noite, e depois periodicamente entre as sessões de canto e dança que se seguem até o amanhecer. Tal como os Criadores imitaram os sons dos insetos para dividir a noite, às vezes por meio da lança-chocalho, às vezes usando a própria voz.

A lança é tema de comentários elaborados, que enfatizam seu papel no controle do tempo. Além das gravuras do sol e da lua, o topo plumado da lança é o rosto do sol; a haste sendo sua coluna dorsal, um eixo cósmico (axis mundii), 
unindo as diferentes camadas do universo. A dilatação distal do chocalho é o recipiente em que se guardava a noite, com suas duas incisões a representar a divisão entre o dia e a noite, e a ponta representando a chave da caixa. A lança também serviu como um compasso, guiando os ancestrais à medida que viajavam do leste, rio acima na canoa ancestral, e serviu como um gnômon que lhes permitiu encontrar a região em que agora vivem: fincado verticalmente no solo, ao meio-dia não produz sombra (Galvão \& Galvão, 2004: 29).

Por fim, a lança e a caixa são guardadas juntas, como um par, penduradas conjuntamente em um cipó amarrado ao teto, de um dos lados da parte central da maloca. Oposto a elas, do outro lado do espaço central, fica o mastro que é utilizado para iluminar a maloca durante a noite: a luz emana da queima de uma resina colocada em seu topo ou de lascas de madeira inseridas em um talho lateral (ver imagem I na pág. 686). Esse mastro e a combinação de lança-solar e caixa de pena são assimilados como fontes de luz. Eles também são contrastados, de um lado com a luz metafórica de um conjunto de artefatos, de outro com a chama luminosa de um produto flamejante da floresta.

\section{CONCLUSÃO - O CONTROLE DO TEMPO EM UM UNIVERSO EM EXPANSÃO}

Armados com essa complexa rede de informações sobre a natureza e as associações dos chicotes e das lanças-chocalho, seus papéis e suas relações com a caixa de penas, podemos agora começar a reunir as peças do quebra-cabeça, espalhadas nesse conjunto de narrativas, de modo a colocar em foco a imagem maior.

Ao comentar a relação entre folhas, penas e cabelo, notamos que o universo, a maloca e a caixa de penas estão relacionados como um conjunto de recipientes em que o universo engloba a maloca, que, por sua vez, engloba a caixa de penas. Antes da aquisição das casas, do caraná e da noite, os Criadores viviam dentro de uma única maloca, coextensiva ao universo. Porém, dentro dessa Maloca-Universo, havia outra maloca menor, habitada por um Dono poderoso, que controlava os materiais de que os Criadores necessitavam. Em relação aos Criadores em sua Maloca-Universo, a maloca do Dono era como uma caixa de penas, uma fonte de penas, contida na Maloca-Universo. Do ponto de vista do Dono, sua maloca continha uma caixa de penas ainda menor: aquela que ele deu aos Criadores. Tudo isso é muito claro nas histórias sobre a noite. Do lado de fora, no Universo-Maloca, havia um dia eterno e sem divisão. Mas, dentro da maloca do Dono, a noite e o dia não somente existiam, como transcorriam em duas escalas distintas. O Dono ensinou os encantamentos necessários durante a noite, e indicou o momento apropriado para cada fórmula xamanística. Então ele deu aos visitantes a própria noite, encerrada na caixa (ver imagem 2 na página 687).

As narrativas destacam, reiteradamente, uma situação inicial em que a terra, as árvores, as folhas de colmo ou a noite estão confinadas em um único 
pacote ou recipiente, e uma situação final em que, sendo liberadas explosivamente pelas ações tolas dos Criadores, esses materiais, doravante, distribuem-se aleatoriamente pelo mundo. Com a liberação das árvores e das folhas, agora é possível haver diferentes malocas individuais dentro da Maloca-Universo, cada uma delas contendo sua própria caixa de penas como um recipiente ainda menor dentro de si. Essa é uma mudança em escala na qual o universo se expandiu para sua forma presente. A mudança em escala também se aplica aos Criadores, pois, tão logo obtiveram os materiais de que precisavam, tornaram-se Donos por direito. E o mesmo ocorre cada vez que um indivíduo constrói uma nova maloca, toma posse de uma caixa de ornamentos e inicia uma carreira como patrocinador de danças-rituais. Ele também se torna um Dono. Esse é o fardo implicado na lição que as narrativas repetidamente enfatizam: a construção de uma maloca e a organização de rituais que são parte integrante da vida na maloca são trilhas para o poder, mas também acarretam pesadas responsabilidades e perigos potenciais. Tais responsabilidades e perigos existem tanto na escala humana quanto na escala cósmica. Os rituais na maloca - nos quais se utilizam a lança-chocalho, a caixa de penas e os ornamentos - são, ao mesmo tempo, eventos, e posições sociais são negociadas e ocasiões dedicadas ao controle ritual do tempo.

Podemos, agora, entender a razão pela qual o Dono da Noite tanto insistiu para que os Criadores abrissem a caixa da noite no momento certo e no lugar correto (quando tivessem um fogo aceso para iluminar o interior da maloca e se tivessem preparado para a dança ritual). Embora a noite ainda não existisse para os Criadores, eles deveriam abrir a caixa em um tempo destinado a ser o tempo da noite. Essa é a ordem apropriada das coisas, o período em que, hoje, a dança ritual ocorre dentro da maloca. O duplo erro dos Criadores (tanto no tempo como no espaço), abrindo a caixa durante o dia e na floresta, causou uma mudança de escala violenta e descontrolada entre a caixa de penas, a maloca e o universo. Essa expansão em escala, que colocou o tempo em movimento, é o equivalente da inversão entre interior e exterior. A noite, que estava dentro da caixa, agora permanece fora, na Maloca-Universo, envolvendo os Criadores (ver também Fontaine, 20I4: 56, 68, 73). O que havia dentro transformou-se no que há fora, e os conteúdos transformaram-se em continente.

Considerando a equivalência entre o universo, a maloca e a caixa de penas, observemos com mais detalhes de que modo opera o ritual de controle do tempo. Durante o dia, a luz do sol ilumina o interior do universo: o som predominante é o canto dos pássaros (em geral) coloridos, e o ruído dos grilos e de outros insetos se esvai, ao fundo. Dentro da maloca, a situação é inversa: o exterior é iluminado pelo sol, o interior se mostra muito escuro e nenhuma luz (solar) é emitida pelo mastro de luz ou por seu par gêmeo do outro lado, os ornamentos de penas e a lança-chocalho. Os ornamentos estão dentro da caixa, o topo da lança está coberto em uma bainha protetora e não há canto 
ou dança. Dentro da caixa de penas, a maloca da "gente adorno", a situação é, novamente, inversa: o exterior é escuro, porém o interior é de um intenso amarelo, iluminado por ornamentos solares, pessoas à sua própria maneira que, sem dúvida, ali cantam e dançam, pois esse é seu tempo noturno - o mundo fora da caixa, na maloca, está na escuridão.

Na noite em que há dança ritual, todos os termos se invertem: o interior do universo está escuro, somente se vê a luz tênue da lua e das estrelas, não há cores visíveis, nem canto de pássaros - mas, o som dos insetos preenche o ar. O exterior da maloca está escuro, mas o interior é iluminado por uma chama de resina, queimando no mastro de luz. Os ornamentos são cuidadosamente retirados da caixa e distribuídos entre os dançarinos - uma repetição da primeira abertura catastrófica da caixa de penas, porém, dessa vez, sob condições meticulosamente controladas, tal como foi ensinado originalmente pelo Dono da Noite. Em vez de estarem envoltos em escuridão, os dançarinos agora vestem os ornamentos, um a um, até que estejam adornados em trajes de luz. Eles se tornam iguais aos Criadores e dançam ao redor da maloca, que agora se situa em uma escala cósmica. Ao mesmo tempo, se o exterior da caixa de penas está iluminado pela dança, seu interior está escuro, pois os ornamentos estão ausentes. À medida que dançam junto ao corpo dos dançarinos, eles também, os adornos, aumentam de escala. Finalmente, quando o sol se levanta no céu e um novo dia irrompe lá fora, o ciclo recomeça, outra vez: a dança termina, os grilos silenciam, os ornamentos são acondicionados na caixa e o interior da maloca está novamente escuro - "noite" (ver diagrama na pag. 689).

Tudo isso me leva de volta ao começo. Vimos que a caixa de penas é, de fato, um operador espaçotemporal, uma máquina do tempo que, como o sol, transforma o dia em noite e a noite em dia. Mas, no percurso, aprendemos muito mais do que isso. Explorando a relação entre o caraná e as penas, demonstrei como o significado da caixa se estende profundamente aos detalhes dos materiais, cores e texturas. Também demonstrei que muito do conteúdo simbólico da caixa reside em sua relação com outros conjuntos de objetos: de um lado as castanhas e potes que servem como recipientes alternativos para a noite, de outro, a lança-chocalho. Sugeri que o pote da noite poderia ser o pote empregado para armazenar curare, mas isso, para ser devidamente demonstrado, carece ainda de mais conversas com os indígenas da região. A lança-chocalho me leva a um comentário final.

Em uma discussão sobre como o tempo e as estações do ano são codificados acusticamente na mitologia sul-americana, Lévi-Strauss (I 973: 36I-422) estabelece uma analogia entre os sons produzidos por instrumentos percussivos ameríndios e os badalos e chocalhos da Europa, conhecidos como "instrumentos das trevas", que soavam no lugar dos sinos das igrejas no período da Páscoa, ao final da Semana Santa. Fazendo referência à narrativa bem semelhante àquelas que vimos considerando acima, na qual a noite é oriunda 


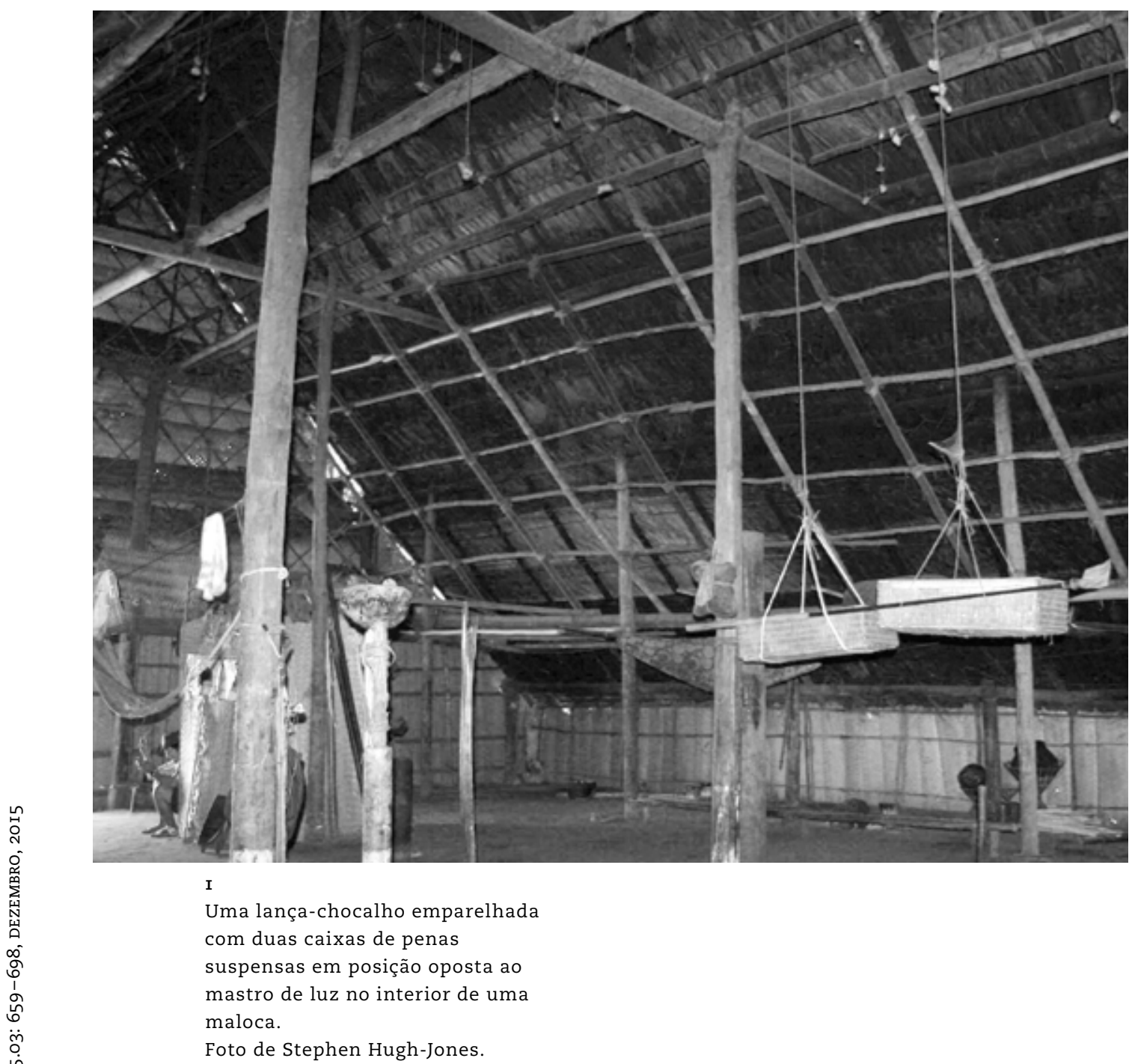




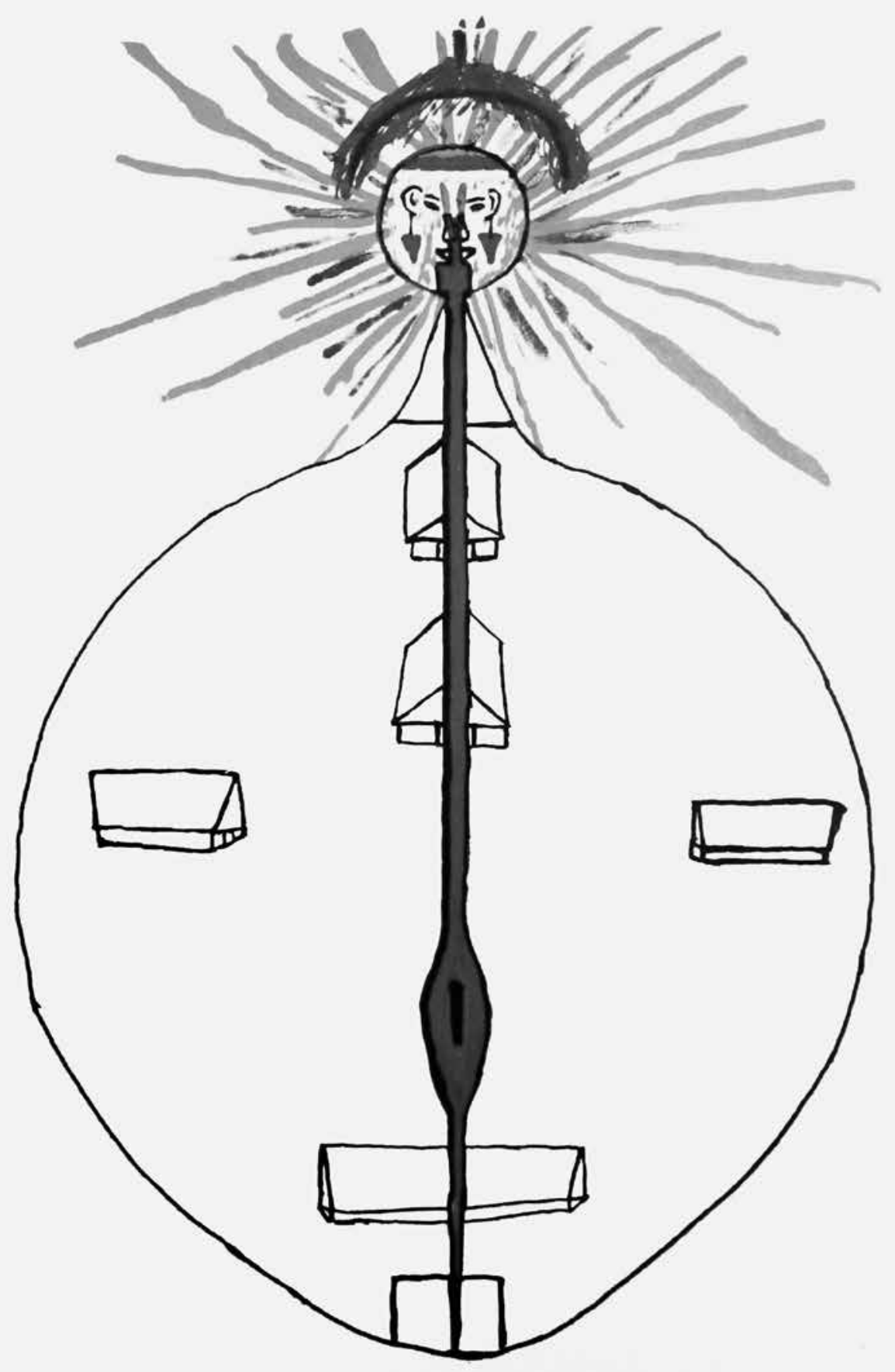


do interior de uma noz, Lévi-Strauss observa que essa noz é um instrumento da escuridão no sentido literal - ela contém a noite -, enquanto seus análogos europeus somente o são em um sentido figurado. A ligação destes últimos com as "trevas" provém da associação com a escuridão que cobriu a Terra quando Cristo morreu, e com os antigos ritos envolvendo a extinção e a renovação dos fogos domésticos. Contudo, apesar da ênfase na dimensão sonora, Lévi-Strauss não encontrou exemplos ameríndios convincentes no que diz respeito à oposição entre os aspectos musical e visual dos instrumentos da escuridão.

Ora, as relações entre a caixa de penas e a lança-chocalho parecem-me um exemplo perfeito do tipo de fenômeno que Lévi-Strauss tinha em mente. Vemos que os dois objetos operam em conjunto mediante uma combinação de registros visuais e auditivos. A caixa de penas é, ao mesmo tempo, um instrumento da escuridão e um instrumento da luz, pois combina a noite e o dia, sol e lua. Dessa forma, a caixa é fundamentalmente um instrumento visual, mas, de várias maneiras, é também musical: nela bate-se com um chicote, emitindo sons percussivos; ela contém os adornos que são intrinsecamente ligados ao canto e à dança; e os dançarinos que se enfeitam com os ornamentos também usam chocalhos noturnos, cujo som é o som dos insetos noturnos. Por sua vez, a lança-chocalho (sendo um maracá alongado) é fundamentalmente um instrumento musical, mas também é um instrumento de luz, possuindo seus próprios ornamentos celestiais. Quando a caixa é aberta, libera os adornos que colocam o tempo em movimento, mas com o risco de trocar um extremo pelo outro, uma noite longa que substitui um longo dia. O som da lança e o cantar e dançar que a acompanham reduzem a duração da noite longa, garantindo a alternância equilibrada de noite e dia.

Com esta conclusão, também tentei dar sentido a um grande corpus de narrativas (que nos chegaram, algumas, em versões bastante empobrecidas, fragmentos de outras versões maiores), procurando relacioná-las umas às outras e devolvendo o conjunto a seus contextos etnográficos. Ao mesmo tempo, em um movimento reverso, analisei as narrativas para lançar nova luz sobre aspectos de uma cultura comum e compartilhada em grande parte do noroeste amazônico. Em particular, vimos como a manipulação ritual de objetos serve como meio de controle do tempo. Foi necessário abordar o assunto em termos bastante gerais, pois um tratamento detalhado do complexo universo ritual me desviaria do foco deste ensaio.

Seguramente, minha explicação é muito distinta daquela que um kumu tukano poderia fornecer. O kumu colocaria ainda mais camadas de referências míticas e listas de propriedades perigosas e protetoras de lugares, coisas e ações. Minha análise utiliza um tipo de estratificação bastante diferente, mas ainda assim baseia-se nos mesmos materiais dos quais o kumu deriva sua "curación del tiempo" [cura do tempo]. O objetivo do kumu é proteger seu povo e garantir a continuação da ordem do mundo. Meu objetivo tem sido oferecer 


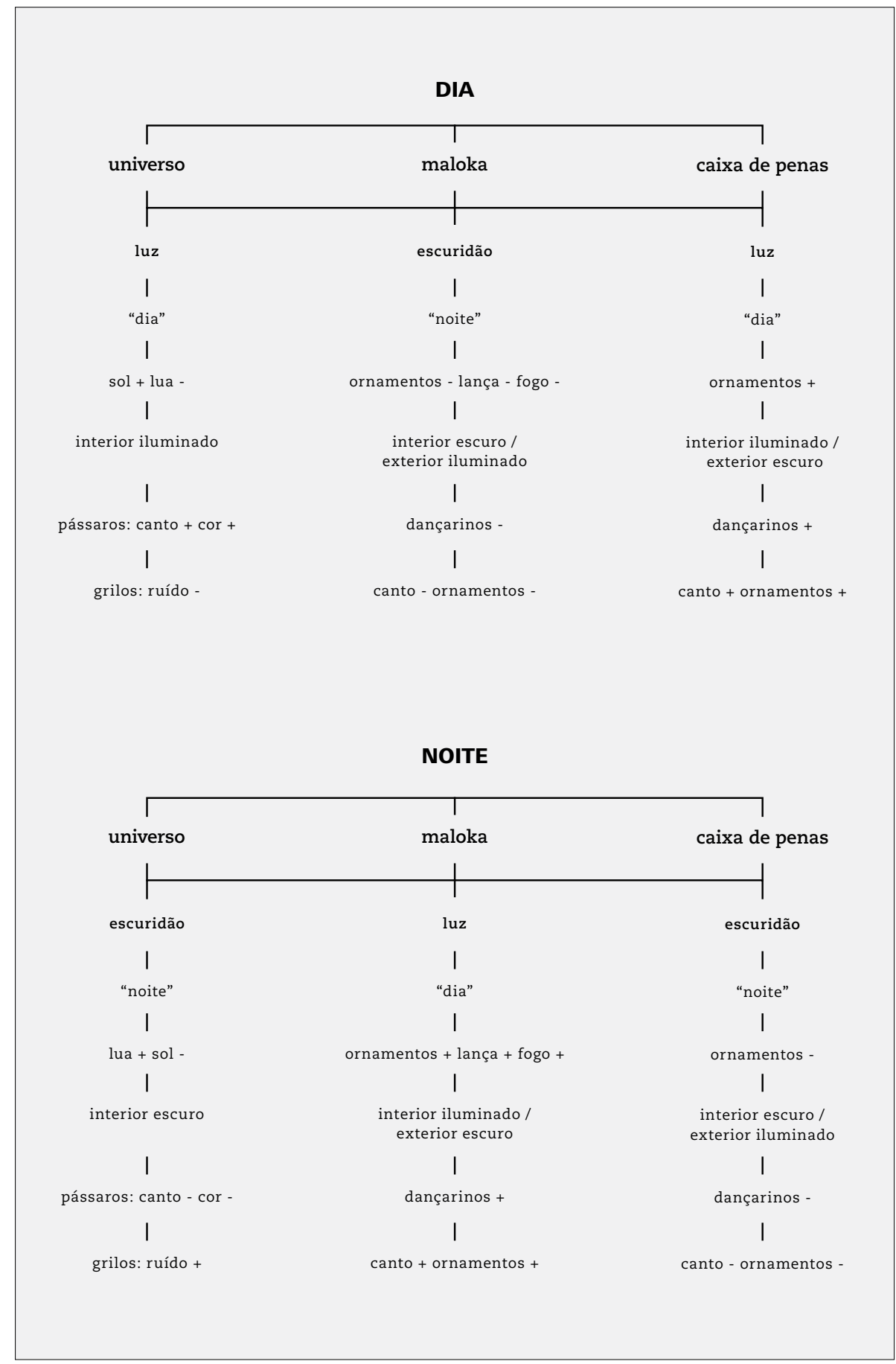

diagrama

Inversões entre exterior e interior do dia para a noite 
690

entendimento das histórias que sustentam esse controle ritual do tempo. Como parte do exercício, também tentei explicar por que a palavra que designa "sol" também indica o "caraná". À primeira vista, isso parece apenas outro caso desinteressante de homonímia. Observando de perto, percebemos que toda uma cosmologia está escondida sob as folhas de colmo.

Recebido em 20/09/20I5 | Aprovado em 07/I0/2015 


\section{NOTAS}

I Em uma variante do tema da caixa de duas cores, uma história kubeo fornece o seguinte detalhe: após a primeira noite, Odoborü, o Morcego e Dono do Dia, foi checar se a noite e o dia estavam na ordem apropriada. Ele foi até o Grande Rio, onde todos os rios terminam, e trouxe de volta dois tipos de cinza, um branco e outro preto, que colocou no topo da caixa de penas (Correa, I992: 48; Correa, I997: 64).

2 Na realidade, as histórias vão de versões mais "fracas" em que os Criadores são apenas instruídos de que devem ter lenha para produzir bastante fogo (por exemplo, Matapí \& Matapí, s.d.: 6I), passam por versões "intermediárias" nas quais são instruídos a preparar cerveja de mandioca e fazer a pintura corporal, pré-requisitos do ritual (por exemplo, Acaipi, s.d.; Buchillet, I983; Galvão \& Galvão, 2004), até chegar em versões mais "fortes" em que a dança é explícita (por exemplo, Azevedo \& Azevedo, 2003:I88-I9I; Reis, 2013: 66).

3 Aqui o foco é geralmente no contraste entre a jacutinga de cabeça branca (Aburria pipile) e o jacu de Spix (Penelope jacquacu), que lida com as diferentes cores e cantos dos dois pássaros, além dos dois momentos distintos em que estão ativos antes da alvorada. Um tratamento detalhado desse tema está além do escopo deste ensaio, porém, sobre "pássaros-relógio", ver Lévi-Strauss (I970: 204, nota 3).

4 Isso replica com certa precisão o que é contado na área Pirá-paraná. Ver também Correa, I992; I996 e Trupp, I977 e o tema mais geral do recipiente que emite sons de grilos ou que está cheio destes.

\section{REFERÊNCIAS BIBLIOGRÁFICAS}

Optamos por indicar entre colchetes, e após a referência das obras em que estão registradas, as narrativas (e suas versões) e os respectivos grupos indígenas no noroeste amazônico junto aos quais elas foram obtidas. Deste modo, preservamos a intenção do autor no manuscrito original e ao mesmo tempo valorizamos a sua extensa pesquisa. [N.E] 
Acaipi. (s.d.) Hee yaia godo makari. El territorio de los jaguares de Yuruparí. Conocimiento para el manejo del medio ambiente por los indígenas del Río Pirá Paraná. Bogotá: Fundación Gaia-Amazonas, mimeo. [Los Ayawa piden tierra fértil, la noche, los arboles y las hojas de techar, p. 59-69 (Makuna)].

Andrello, Geraldo. Os Diroa procuram a noite, mimeo (Tariano).

Århem, Kaj et al. (2004). Etnografía Makuna. Bogotá: Instituto Colombiano de Antropologia e Historia. [La maloka, la noche y el sueño, p. 472-479 (Makuna)].

Azevedo, Miguel \& Azevedo, Antenor Nascimento. (2003). Dahsea Hausirõ Porã ukũsehe wiophesase merãbueri turi. Mitologia sagrada dos Tukano Hausirõ Porã. São Gabriel da Cachoeira/São José I, Rio Tiquié: FOIRN/UNIRT. [História de Pûsua bükü, p. I48-I5I; Origem da noite, p. I88-I9I (Tukano)].

Barroso Baré, Marivelton. (20I5). Kurumim wasú. In: Herrero, Marina \& Fernandes, Ulysses (orgs.). Baré: povo do rio. São Paulo: Sesc. [A origem da noite, p. 25 (Baré)].

Beksta, Casimiro. (1984). A maloka Tukano-Desana e seu simbolismo. Dissertação de Mestrado. Universidade Federal do Amazonas.

Bidou, Patrice. (1972). Représentations de l'éspace dans la mythologie Tatuyo. Journal de la Société des Américanistes, 6I, p. 45-I05. [Sem título, p. 99 (Tatuyo)]

Biocca, Ettore. (2007). Viaje entre los indígenas del alto rio negro. Trad. Beatriz Alzate Angel. Bogotá: Instituto Italiano de Cultura.

Blixen, Olaf. (20 I I). La luz y las tinieblas. El día y la noche en la mitología sudamericana. Archivos, IX, Centro de Investigaciones en Antropología Filosófica y Cultural de la Asociación Argentina de Cultura, p. 33-I49. Disponível em <http://www. ciafic.edu.ar/documentos/o2_Archivos_20I I_La_Luz_y_las_ Tinieblas_pp_33-I49.pdf>. Acesso em 29 nov. 2015.

Bourgue, François. (I976). Los caminos de los hijos del cielo. Estudio socio-territorial de los kawillary del Cananari y del Apaporis. Revista Colombiana de Antropología, 20, p. Io I-I44. [Mito de los Munully, p. I38-I43 (Kawiyerí)]. 
Buchillet, Dominique. (1983). Maladie et memoire des origines chez les Desana du Uaupes (Brésil). Tese de Doutorado. Université de Paris X - Nanterre. [Origine de la nuit, p. 200-202 (Desana)].

Cornelio, José Marcellino et al. (I999). Waferinaipe Ianheke. A sabedoria dos nossos antepassados: histórias dos Hohodene e dos Walipere-Dakeni do rio Aiari. Rio Aiari/São Gabriel da Cachoeira: ACIRA/FOIRN. [Nhãpirikuli procura a terra, a noite e o tabaco, p. 74-76; Nhãpirikuli procura a noite, $p$. 79-80 (Baniwa)].

Correa, François (org.). (I997). Los Kuwaiwa: creadores del universo, la sociedad y la cultura. Quito: Ediciones Abya-Yala. [La noche, p. 6o-65; Historia de la maloka, p. I5I-I54; Historia de la maloka, p. I67-170 (Kubeo)].

Correa, François. (I996). Por el camino de la Anaconda Remedio. Bogotá: Universidad Nacional de Colombia. [Los Ayawaroa, p. 342-345 (Taiwano)].

Correa, François (org.). (I992). Relatos míticos Cubeo: indígenas del Vaupés. Bogotá: Servicio Colombiano de Comunicación. [La maloka, p. 35-39; La noche, p. 47-5I; comentario, p. I 2 I- I 23 (Kubeo)].

Correa, François (org.). (I989). Relatos míticos Kabiyari. Bogotá: Servicio Colombiano de Comunicación. [Los hijos del cielo; Compra de la noche; Taru, el oso palmero, p. 37-42 (Kawiyerí)].

Costa, Luiz A. L. (2010). The Kanamari Body-Owner. Predation and feeding in Western Amazonia. Journal de la Société des Américanistes, 96/I, p. I69-I92.

Dutra, Israel. (20I I). A história de origem espiritual dos povos indígenas do Uaupés. Tellus I I/2 I, p. 235-253. [Tuyuka].

Epps, Patience \& Stenzel, Kristine (orgs.). (2013). Upper Rio Negro: cultural and linguistic interaction in Northwestern Amazonia. Rio de Janeiro: Museu Nacional/Museu do Índio/Funai. Fausto, Carlos. (2008). Donos demais: maestria e domínio na Amazônia. Mana, I4/2, p. 329-366.

Fernandes, Américo \& Fernandes, Dorvalino. (1996). A mitologia sagrada dos Desana-Wari Dihputiro Põrã. São Gabriel da Cachoeira: UNIRT. [Os Ümüri masa procuram a noite, p. 93-IоI (Desana)]. 
Fontaine, Laurent. (20I4). La nuit pour apprendre. Le chamanism nocturne des Yucuna d'Amazonie colombienne. Paris: Société d'Ethnologie. [Yukuna].

Fontaine, Laurent. (2010). Obligations et pouvoirs nocturnes chez les indians Yucuna. Current Anthropology, 51/6, p. 826-827. [Yukuna].

Fulop, Marcos. (2009) [1954]. Aspectos de la cultura Tukana: cosmogonia e mitologia. Trad. Casimiro Beksta. Manaus: EDUA. [Sem título, p. 46-5I (Tukano)].

Galvão, Wenceslau Sampaio \& Galvão, Raimundo Castro. (2004). Liuro dos Antigos Desana-Guahari Diputiro Porã. São Gabriel da Cachoeira/Comunidade Pato: FOIRN/ONIMRP. [Os Desana foram buscar a mala da noite, p. 427- 433 (Desana)].

Goldman, Irving. (2004). Cubeo Hehenewa religious thought: metaphysics of a Northwest Amazonian People. Nova York: Columbia University Press. [Sem título, p. I6o-I63 (Kubeo)]. Hill, Jonathan. (2009). Made-from-bone: trickster myths, music, and history from the Amazon. Urbana: University of Illinois Press. [Grandfather sleep; or The origin of night, p. 75-80 (Baniwa)].

Hugh-Jones, Stephen. (20I4). Caixa de pandora: estilo alto-rio-negrino.R@U - Revista de Antropologia da UFSCar, 6/I, p. I55-I73.

Hugh-Jones, Stephen. (2013). La Palma y los Pléyades. Bogotá: Universidad Central.

Hugh-Jones, Stephen. (2009). The fabricated body: objects and ancestors in Northwestern Amazonia. In: SantosGranero, Fernando (org.). The occult life of things: native Amazonian theories of materiality and personhood. Tucson: University of Arizona Press.

Hugh-Jones, Stephen. (I979). The Palm and the Pleiades. Cambridge: Cambridge University Press. [The Ayawa obtain night, p. 267-268 (Barasana)].

Jacopin, Pierre-Yves. (I972). Habitat et territoire yukuna. Journal de la Société des Américanistes, 6I, p. I07-I39. [Le discours mythique, p. I I4-I I6 (Yukuna)].

Koch-Grünberg, Theodor. (I908). Jagd und waffen bei den indianern nordwestbrasiliens. Globus, 93/13, p. I97-203; p. 
2I5-22I. Disponível em <http://digi-alt.ub.hu-berlin.de/ viewer/resolver?urn=urn\%3Anbn\%3Ade\%3Akobv\%3A I I -d-4202254>. Acesso em 29 nov. 2015.

Lana, Feliciano Pimentel. (2009). A origem da noite \& Como as mulheres roubaram as flautas sagradas. Manaus: EDUA. [A origem da noite, p. 3I-66 (Desana)].

Lana, Firmiano Arantes \& Lana, Luiz Gomes. (1980). Antes o mundo não existia: mitologia dos antigos Desana-K-híriporã. I.ed. São Paulo: Livraria Cultura. [A estória de Ñami ou a origem da noite, p. Io9-I I 2 (Desana)].

Lévi-Strauss, Claude. (I973). From honey to ashes. London: Jonathan Cape.

Lévi-Strauss, Claude. (I955). The structural study of myth. Journal of American Folklore, 68/270, p. 428-444.

Matapi, Alaruna \& Matapi, Pewami. (I984). Literatura oral matapi. Bogotá: Centro Cultural Jorge Eliécer Gaitán. [Kajipu lakena, p. 8-ı5 (Yukuna)].

Matapí, Huai \& Matapí, Turipi. (s.d.). La creacion del mundo y la historia de los Matapí, mimeo. [La creacion de la maloka, p. 29-42; La creacion de la primera noche, p. 43-6I (Yukuna)].

Matapí, Uldarico et al. (2010). Seres emplumados: el arte plumario en la Amazonia colombiana desde la visión local. Bogotá: Instituto Alexander von Humbolt/Tropenbos International Colombia. [Sem título, p. I9-28 (Yukuna)].

Oliveira, Melissa. (s.d.) Astronomia Tukano. Disponível em <http://pib.socioambiental.org/pt/c/no-brasil-atual/ modos-de-vida/astronomia-tukano>. Acesso em 29 nov. 20I5. [Tukano].

Palma, Milagros. (I994). Los viajeros de la Gran Anaconda: mitos y leyendas de los Letuama de la Amazonia. Bogotá: Indigo. [El origen de la noche, p. 66-72 (Letuama)].

Palma, Milagros. (I99I). Les Letuamas, gens de l'eau: mythes et légendes de l'Amazonie. Paris: Côté-femmes. [L'origine de la nuit, p. 68-72 (Letuama)].

Piedade, Acacio. (I 997). Ye Pa-Masa: por uma antropologia da música no alto Rio Negro. Dissertação de Mestrado. Programa de Pós-Graduação em Antropologia Social/Universidade Federal de Santa Catarina. [A origem da noite e do sono, p. I7I-I73 (Tukano)]. 
Reichel-Dolmatoff, Gerardo. (I97I). Amazonian cosmos. Chicago: University of Chicago Press. [Sem título, p. 26 (Desana)].

Reis, Olavo. (2013). A cruz do Turi: uma contribuição à etnografia do profetismo no Rio Uaupés. Dissertação de Mestrado. Universidade Federal de São Carlos. [História de ÑamĩriWi’i Umurĩ-Masã, p. 65-68 (Desana)].

Rojas Sabana, Filintro Antônio. (1997). Ciencias naturales en la mitologia Curripaco. Bogotá: Fundación Etnollano. [Origen de la noche, p. I25-I26; Las estrellas y las constelaciones, p. I27-I 29 (Kurripaco)].

Romero Raffo, Manuel. (2003). Malikai. El canto del Malirri: formas narrativas en un mito amazónico. Bogotá: Centro de Estudios de la Realidad Colombiana/Fundación Parature. [El comienzo de este mundo, p. 50; En busca de la noche, p. 53 (Kurripaco)].

Schackt, Jon. (2013). A people of stories in the forest of myth: the Yukuna of Miritiparaná. Oslo: Novus Press. [The first maloka and the works of the Karipúlakena, p. II6-I 20 (Yukuna)].

Schauer, Stanley \& Schauer Junia. (I975). Texto yucuna: la historia de los Caripu Iaquena. In: Folclor indígena de Colombia, Tomo I. Bogotá: Ministerio de Gobierno, p. 252333. Disponível em <https://archive.org/details/rosettaproject_ycn_vertxt-I>. Acesso em 29 nov. 20I5. [Yukuna].

Silva, Alcionilio Bruzzi da. (1994). Crenças e lendas do Uaupés. Cayambe: Abya-Yala. [A primeira noite, p. I73-I75 (Baniwa)].

Silverwood-Cope, Peter L. (I990). Os Makú: povo caçador do nordeste da Amazônia. Brasília: Ed. UnB. [Idn Kamni vai buscar a Noite, p. I4I-I42 (Kakua-Makú)].

Trupp, Fritz. (1977). Mythen Makuna. Viena: Elizabeth Stiglmayr. [Die Adyawas, p. 30-37 (Makuna)].

Van der Hammen, Maria Clara. (I99I). El manejo del mundo. Bogotá: Tropenbos. [El origen de la palma caraná, p. I06; El origen de la hoja para techar, p. I40; El origen de los animales nocturnos, p. 286-287 (Yukuna)].

Von Hildebrand, Martín. (1984). Notas etnográficas sobre el cosmos Ufaina y su relación con la maloka. Maguaré, 2, 
p. I77-2 Io. [Los Imararimaka hacen la Primer Maloca, p. I9 I-I96 (Tanimuka)].

Von Hildebrand, Martín. (I975). Origen del mundo según los Ufaína. Revista Colombiana de Antropología, XVIII, p. 32 I382. [Tanimuka].

Wright, Robin. (I98I). History and religion of the Baniwa peoples of the upper Rio Negro Valley. 2 vols. Tese de doutorado. Stanford University. [Yperikuli obtains the earth, the container of night, and tobacco, p. 564-566 (Baniwa)]. 


\section{A ORIGEM DA NOITE: E POR QUE O SOL É CHAMADO DE "FOLHA DE CARANÁ"}

A partir da análise de um amplo conjunto de narrativas sobre a origem da noite, obtidas junto aos povos indígenas da bacia do Alto Rio Negro no noroeste amazônico, este artigo explora o modo como esses povos representam a alternância entre o dia e a noite em diferentes planos de significantes - nos sons e cores dos insetos, pássaros e animais da floresta; nos materiais, texturas e cores de suas casas e objetos; no corpo humano; e na música e na dança rituais. Este último plano nos permitirá compreender o ritual como um mecanismo de controle do tempo. Além disso, espero lançar luz sobre as razões pelas quais, em muitas línguas da família Tukano Oriental, os termos para "sol" e para "lua" significam também, respectivamente, "colmo" e "folha".

\section{THE ORIGIN OF NIGHT: AND WHY THE SUN IS CALLED "CARANÁ LEAF"}

Abstract

By analysing a wide set of narratives on the origin of night found among the Indigenous people of the upper and night at different levels of meaning: in the sounds and colours of insects, birds and forest animals; in the material, texture and colour of their houses and objects; in the human body; and in ritual music and dance. This latter level allows us to understand ritual as a mechanism for controlling time. The article also investigates why, in many Eastern Tukanoan languages, the terms for 'sun' and 'moon' also mean, respectively, 'culm' and 'leaf'.
Palavras-chave

Mito;

Origem da noite;

Ritual;

Noroeste amazônico;

Etnologia indígena.
Keywords

Myth;

Origin of night;

Ritual;

Northwest Amazonia; Indigenous ethnology. 